\title{
Net global warming potential and greenhouse gas intensity in a double-cropping cereal rotation as affected by nitrogen and straw management
}

\author{
T. Huang ${ }^{1}$, B. Gao ${ }^{1}$, P. Christie ${ }^{1,2}$, and X. Ju ${ }^{1}$ \\ ${ }^{1}$ College of Resources and Environmental Sciences, China Agricultural University, Beijing 100193, China \\ ${ }^{2}$ Agri-Environment Branch, Agri-Food and Biosciences Institute, Belfast BT9 5PX, UK \\ Correspondence to: X. Ju (juxt@cau.edu.cn)
}

Received: 25 June 2013 - Published in Biogeosciences Discuss.: 8 August 2013

Revised: 30 October 2013 - Accepted: 3 November 2013 - Published: 4 December 2013

\begin{abstract}
The effects of nitrogen and straw management on global warming potential (GWP) and greenhouse gas intensity (GHGI) in a winter wheat-summer maize doublecropping system on the North China Plain were investigated. We measured nitrous oxide $\left(\mathrm{N}_{2} \mathrm{O}\right)$ emissions and studied net GWP (NGWP) and GHGI by calculating the net exchange of $\mathrm{CO}_{2}$ equivalent $\left(\mathrm{CO}_{2}\right.$-eq) from greenhouse gas emissions, agricultural inputs and management practices, as well as changes in soil organic carbon (SOC), based on a long-term field experiment established in 2006. The field experiment includes six treatments with three fertilizer $\mathrm{N}$ levels (zero $\mathrm{N}$ (control), optimum and conventional $\mathrm{N}$ ) and straw removal (i.e. $\mathrm{N}_{0}, \mathrm{~N}_{\text {opt }}$ and $\mathrm{N}_{\text {con }}$ ) or return (i.e. $\mathrm{SN}_{0}, \mathrm{SN}_{\text {opt }}$ and $\mathrm{SN}_{\text {con }}$ ). Optimum $\mathrm{N}$ management $\left(\mathrm{N}_{\mathrm{opt}}, \mathrm{SN}_{\mathrm{opt}}\right)$ saved roughly half of the fertilizer $\mathrm{N}$ compared to conventional agricultural practice $\left(\mathrm{N}_{\text {con }}, \mathrm{SN}_{\text {con }}\right)$, with no significant effect on grain yields. Annual mean $\mathrm{N}_{2} \mathrm{O}$ emissions reached $3.90 \mathrm{~kg} \mathrm{~N}_{2} \mathrm{O}-\mathrm{N} \mathrm{ha}^{-1}$ in $\mathrm{N}_{\text {con }}$ and $\mathrm{SN}_{\text {con }}$, and $\mathrm{N}_{2} \mathrm{O}$ emissions were reduced by $46.9 \%$ by optimizing $\mathrm{N}$ management of $\mathrm{N}_{\text {opt }}$ and $\mathrm{SN}_{\text {opt }}$. Straw return increased annual mean $\mathrm{N}_{2} \mathrm{O}$ emissions by $27.9 \%$. Annual SOC sequestration was $0.40-1.44 \mathrm{Mg} \mathrm{Cha}^{-1} \mathrm{yr}^{-1}$ in plots with $\mathrm{N}$ application and/or straw return. Compared to the conventional $\mathrm{N}$ treatments the optimum $\mathrm{N}$ treatments reduced NGWP by $51 \%$, comprising $25 \%$ from decreasing $\mathrm{N}_{2} \mathrm{O}$ emissions and $75 \%$ from reducing $\mathrm{N}$ fertilizer application rates. Straw return treatments reduced NGWP by $30 \%$ compared to no straw return because the GWP from increments of SOC offset the GWP from higher emissions of $\mathrm{N}_{2} \mathrm{O}$, $\mathrm{N}$ fertilizer and fuel after straw return. The GHGI trends from the different nitrogen and straw management
\end{abstract}

practices were similar to the NGWP. In conclusion, optimum $\mathrm{N}$ and straw return significantly reduced NGWP and GHGI and concomitantly achieved relatively high grain yields in this important winter wheat-summer maize double-cropping system.

\section{Introduction}

Carbon dioxide $\left(\mathrm{CO}_{2}\right)$, methane $\left(\mathrm{CH}_{4}\right)$ and nitrous oxide $\left(\mathrm{N}_{2} \mathrm{O}\right)$ are the three most important greenhouse gases (GHGs) because of their positive increases in radiative forcing and their longevity in the atmosphere (Mosier et al., 2006; IPCC, 2007). Agricultural GHG emissions were estimated to be $5.1-6.1 \mathrm{Pg}\left(1 \mathrm{Pg}=10^{15} \mathrm{~g}\right) \mathrm{CO}_{2}$ equivalents $\left(\mathrm{CO}_{2}\right.$-eq) in 2005, representing $10-12 \%$ of total global anthropogenic emissions (Smith et al., 2007). Furthermore, agricultural GHG emissions account for roughly $20 \%$ of the increment in radiative forcing of climate change each year (Cole et al., 1997). The mitigation potential from agriculture (excluding fossil fuel offsets from biomass) was estimated to be about 5.5-6.0 $\mathrm{Pg} \mathrm{CO}_{2}$-eq $\mathrm{yr}^{-1}$ if global agricultural techniques were improved by 2030 (Smith et al., 2008). Therefore, agricultural ecosystems are not only a very important source of GHG emissions but also present substantial opportunities for mitigation (Snyder et al., 2009).

In addition to edaphic and climatic conditions, agricultural management practices such as tillage, straw management, fertilization, irrigation and crop rotation significantly affect GHG emissions (Robertson et al., 2000; Huang et al., 2004; 
Mosier et al., 2006). Many long-term field experiments have indicated that proper fertilization together with straw return can increase soil organic carbon (SOC) content (Huang and Sun, 2006; Mosier et al., 2006; Zhang et al., 2010; Shang et al., 2011). However, these practices may also stimulate $\mathrm{N}_{2} \mathrm{O}$ emissions by increasing the supply of substrates for soil nitrifiers and denitrifiers, and the resulting increase in microbial activity may offset the SOC sequestration effects (Pathak et al., 2005). Field practices that change some soil conditions to mitigate one form of GHG emissions may bring about favourable conditions for other forms of emissions and thereby change the overall balance of GHGs (Pathak et al., 2005; Shang et al., 2011; Ma et al., 2013). To measure these overall effects in any given system the concept of net global warming potential (NGWP) was proposed based on the radiative properties of all the GHG emissions and carbon fixation, expressed as $\mathrm{CO}_{2}$-eq ha ${ }^{-1} \mathrm{yr}^{-1}$, to give an integrated evaluation of whether the system is positive or negative in terms of $\mathrm{CO}_{2}$-eq (Robertson and Grace, 2004). Furthermore, in order to measure the magnitude of GHG emissions to produce the same crop yield, another concept, greenhouse gas intensity (GHGI), was introduced and is expressed as the GWP of per unit of crop yield (Mosier et al., 2006). This concept can assist in solving the global challenges of increasing food production and concomitantly decreasing emissions. This also raises the important question of the potential for indirect land use change and GWP by clearing carbon-rich natural ecosystems for crop production (Tilman et al., 2002; Foley et al., 2011).

The North China Plain (NCP) covers an area of 35 million hectares and is one of the most important cereal production areas in China (Ding et al., 2011). Winter wheat-summer maize double-cropping rotations are the dominant cropping system in this region, and rational fertilization, irrigation and straw management are key factors for production of relatively high target yields, nutrient and water use efficiencies, and sustainable environmental conditions (Chen et al., 2011; Meng et al., 2012). Due to numerous interacting economic, social, and policy factors - e.g low on-farm incomes and high off-farm incomes, poor extension services, and relative low $\mathrm{N}$ fertilizer prices through subsidies for $\mathrm{N}$ fertilizer manufacturers over the last two decades - fertilizer $\mathrm{N}$ application rates are in general 30 to $60 \%$ above the agronomic or recommended levels, with $\mathrm{N}$ application rates of 325 and $263 \mathrm{~kg}$ $\mathrm{Nha}^{-1}$ for winter wheat and summer maize, respectively, in conventional farming practice (Ju et al., 2009). The overuse of fertilizer $\mathrm{N}$ in the past will inevitably bring about a range of environmental consequences such as $\mathrm{N}_{2} \mathrm{O}$ emissions (Gao et al., 2011; Ju et al., 2011), nitrate leaching (Ju et al., 2009), soil acidification (Guo et al., 2010) and air pollution (Liu et al., 2013). Recently, our results have shown that $\mathrm{N}_{2} \mathrm{O}$ emissions can be reduced by $61.5 \%$ by optimizing $\mathrm{N}$ management compared to local farming practice (Ju et al., 2011) and consequently reduce emissions of $\mathrm{CO}_{2}$-eq during the manufacture of $\mathrm{N}$ fertilizers (Zhang et al., 2013). However, the SOC content of topsoils on the NCP has increased over the last two decades due to high application rates of synthetic fertilizers and straw return (Huang and Sun, 2006). It remains unclear to what extent NGWP and GHGI can be reduced following optimum $\mathrm{N}$ and straw management in this cropping system in comparison with conventional farming practice.

The energy used for irrigation, fuel consumption for farm operations and application of agrochemicals in crop production systems can also produce large amounts of $\mathrm{CO}_{2}$-eq, which should be taken into account in the estimation of emission sources contributing to GWP (Mosier et al., 2006; Snyder et al., 2009). In our region the winter wheat must be irrigated (about $400 \mathrm{~mm}$ ) to ensure relatively high grain yields because the precipitation during the dry growing season represents only $20-30 \%$ of annual rainfall (Meng et al., 2012). Over-exploitation of the groundwater by agriculture for irrigation during the last three decades has lowered the water level (Wang et al., 2002), and the operation of the pumps requires more electricity, which is mostly generated by coal combustion, thus emitting more $\mathrm{CO}_{2}$-eq (Zhang et al., 2013). The tillage practices developed in the last two decades for this cropping system are also unique, i.e. winter wheat straw mulching and direct seeding of summer maize without tillage, with only annual moldboard ploughing to incorporate maize straw and sow winter wheat and thus promote SOC sequestration and reduce the amount of fuel required for tillage (Huang et al., 2011) as compared to deep tillage for every crop in the past. Moreover, this cropping system normally serves as small sink for $\mathrm{CH}_{4}$, and most results show that $\mathrm{CH}_{4}$ uptake is almost $1 \mathrm{~kg} \mathrm{CH}_{4}-\mathrm{Cha}^{-1} \mathrm{yr}^{-1}$ (Gao, 2012; Liu et al., 2012; Hu et al., 2013). The unique features of soil and climatic conditions together with the management practices of this double-cropping system make it interesting for us to know the integrated changes in GHG emissions after optimum $\mathrm{N}$ and straw management in comparison with conventional farming practice. To our knowledge, few studies have examined the NGWP and/or GHGI of this cropping system (Gao, 2012; Song et al., 2013), and the sources of emissions and carbon fixation were not taken fully into consideration in those studies that did, and as such the tradeoffs between the GWP sources and sinks remain to be explored.

The objectives of the present study were to investigate the effects of $\mathrm{N}$ application rate and straw return on grain yield, $\mathrm{N}_{2} \mathrm{O}$ emissions, topsoil SOC sequestration and the tradeoffs among these in order to calculate and evaluate NGWP and GHGI over two cycles of the double-cropping cereal system based on a long-term field experiment with three $\mathrm{N}$ application rates and two straw management practices (with and without straw return). 
Table 1. Treatments of the long-term field experiment.

\begin{tabular}{lll}
\hline Treatments & Nitrogen management & Straw management \\
\hline $\mathrm{N}_{0}$ & No N application & wheat and maize straw removing \\
$\mathrm{N}_{\text {opt }}$ & Improved Nmin test & wheat and maize straw removing \\
$\mathrm{N}_{\text {con }}$ & Conventional farming practice & wheat and maize straw removing \\
$\mathrm{SN}_{0}$ & No N application & wheat straw mulching and maize straw returning \\
$\mathrm{SN}_{\text {opt }}$ & Improved $\mathrm{N}_{\text {min }}$ test & wheat straw mulching and maize straw returning \\
$\mathrm{SN}_{\text {con }}$ & Conventional farming practice & wheat straw mulching and maize straw returning \\
\hline
\end{tabular}

\section{Materials and methods}

\subsection{Description of study site}

The long-term field experiment started in October 2006 and is located at Shangzhuang Research Station $\left(39^{\circ} 48^{\prime} \mathrm{N}\right.$, $116^{\circ} 28^{\prime} \mathrm{E}$ ) of China Agricultural University in suburban Beijing. The site is at an altitude of $40 \mathrm{~m}$ and has a typical continental monsoon climate. Annual cumulative mean temperature for days with mean temperatures above $10^{\circ} \mathrm{C}$ is $4000-5000^{\circ} \mathrm{C}$ and the annual precipitation is $500-700 \mathrm{~mm}$, of which $60-70 \%$ occurs during the period from July to September. The air temperature and soil temperature at $10 \mathrm{~cm}$ depth, as well as precipitation and irrigation from June 2011 to June 2013, are shown in Fig. 1. The top $20 \mathrm{~cm}$ of the calcareous fluvo-aquic soil has a $28 \%$ clay content, $32 \%$ silt, $40 \%$ sand and a pH of 8.1 (soil : water ratio $1: 2.5$ ). The bulk density is $1.31 \mathrm{~g} \mathrm{~cm}^{-3}$ and the SOC content is $7.1 \mathrm{~g} \mathrm{~kg}^{-1}$, total $\mathrm{N} 0.8 \mathrm{~g} \mathrm{~kg}^{-1}, \mathrm{NO}_{3}-\mathrm{N} 24.5 \mathrm{mg} \mathrm{kg}{ }^{-1}$, $\mathrm{NH}_{4}-\mathrm{N} 1.20 \mathrm{mg} \mathrm{kg}^{-1}$, Olsen P $7.8 \mathrm{mg} \mathrm{kg}^{-1}$ and available $\mathrm{K}$ $76.2 \mathrm{mg} \mathrm{kg}^{-1}$. Detailed information about the study site was presented in a previous paper (Qiu et al., 2012).

\subsection{Experimental design}

The study involved six treatments with three $\mathrm{N}$ levels (zero $\mathrm{N}$ (control), optimum and conventional $\mathrm{N}$ ) with straw removal (i.e. $\mathrm{N}_{0}, \mathrm{~N}_{\mathrm{opt}}$ and $\mathrm{N}_{\mathrm{con}}$ ) and return (i.e. $\mathrm{SN}_{0}, \mathrm{SN}_{\mathrm{opt}}$ and $\mathrm{SN}_{\text {con }}$ ) (Table 1). The design was a completely randomized block with three replicates and each plot was $8 \mathrm{~m} \times 8 \mathrm{~m}=64 \mathrm{~m}^{2}$. Winter wheat was sown at the beginning of October and harvested in the middle of the June of the following year, and summer maize was sown immediately after the wheat and harvested at the end of September. Winter wheat received basal and top-dressed $\mathrm{N}$ fertilizer. $\mathrm{N}$ rates were estimated according to the synchronization of crop $\mathrm{N}$ demand and soil $\mathrm{N}$ supply in $\mathrm{SN}_{\mathrm{opt}}$ and $\mathrm{N}_{\mathrm{opt}}$, i.e. the target crop $\mathrm{N}$ demand minus $\mathrm{NO}_{3}-\mathrm{N}$ in the root zone. The target crop $\mathrm{N}$ demands for basal application and topdressing were 100 and $200 \mathrm{~kg} \mathrm{~N} \mathrm{ha}^{-1}$ in the corresponding root zone depths $0-40$ and $0-100 \mathrm{~cm}$, respectively (Qiu et al., 2012); in $\mathrm{N}_{\text {con }}$ and $\mathrm{SN}_{\text {con }}, \mathrm{N}$ rates followed local conventional farming practice, i.e. $150 \mathrm{~kg} \mathrm{~N} \mathrm{ha}^{-1}$ as basal fertilizer followed by ploughing and $150 \mathrm{~kg} \mathrm{Nha}^{-1}$ at the shooting stage of wheat (Zhao et al., 2006). For summer maize, $\mathrm{N}_{\text {con }}$ was $130 \mathrm{~kg} \mathrm{Nha}^{-1}$ at the four- and ten-leaf stages; the target crop $\mathrm{N}$ demands for $\mathrm{N}_{\text {opt }}$ were 100 and $160 \mathrm{~kg} \mathrm{~N} \mathrm{ha}^{-1}$ topdressing at the four- and ten-leaf stages with the corresponding root zone depths 0 60 and $0-100 \mathrm{~cm}$, respectively, as recommended by Zhao et al. (2006). Phosphorus and potassium fertilizer were applied only as basal fertilizer for winter wheat at rates of $160 \mathrm{~kg}$ $\mathrm{P}_{2} \mathrm{O}_{5} \mathrm{ha}^{-1} \mathrm{yr}^{-1}$ and $90 \mathrm{~kg} \mathrm{~K}_{2} \mathrm{Oha}^{-1} \mathrm{yr}^{-1}$.

\subsection{Field management}

The row spacing of winter wheat (var. Nongda 211) was $15 \mathrm{~cm}$ and the sowing rate was $225 \mathrm{~kg} \mathrm{ha}^{-1}$. The distances in summer maize (var. Zhengdan 958) between rows and plants were 60 and $25 \mathrm{~cm}$, respectively. Chemical fertilizers and chopped maize straw were incorporated into the soil with tillage at the beginning of October before wheat was sown, and the topdressing $\mathrm{N}$ fertilizer was broadcast at the shooting stage of wheat followed by irrigation. $\mathrm{N}$ fertilizer was broadcast before a precipitation event or supplementary irrigation at the four- and ten-leaf stages of summer maize; the wheat straw was mulched on the soil surface after the wheat harvest. Both maize and wheat straws were mechanically chopped into 5-8 cm lengths. All the plants in straw removal plots were cut down manually and removed after yield sampling by hand.

Winter wheat was irrigated before the winter freeze in the year of sowing and at shooting, heading and grain filling. The irrigation rate was dependent on the soil moisture conditions, i.e. $60,60,0$ and $50 \mathrm{~mm}$ in 2011-2012, and 60, 60, 50 and $50 \mathrm{~mm}$ in 2012-2013. An additional $40 \mathrm{~mm}$ of irrigation was supplied to the winter wheat seedlings on 3 October 2011. No irrigation was used for summer maize seedlings in 2011 and 2012 because of rain events. Pesticide (a mixture of dichlorovos and dimethoate) was sprayed on wheat in the middle of April and the middle or end of May. The same pesticide mixture and herbicide (acetochlor) were sprayed after summer sowing of maize. The liquid pesticide mixture was applied again at the beginning of July and a solid granular pesticide (carbofuran) was applied to the top leaves of summer maize at the beginning of August. 


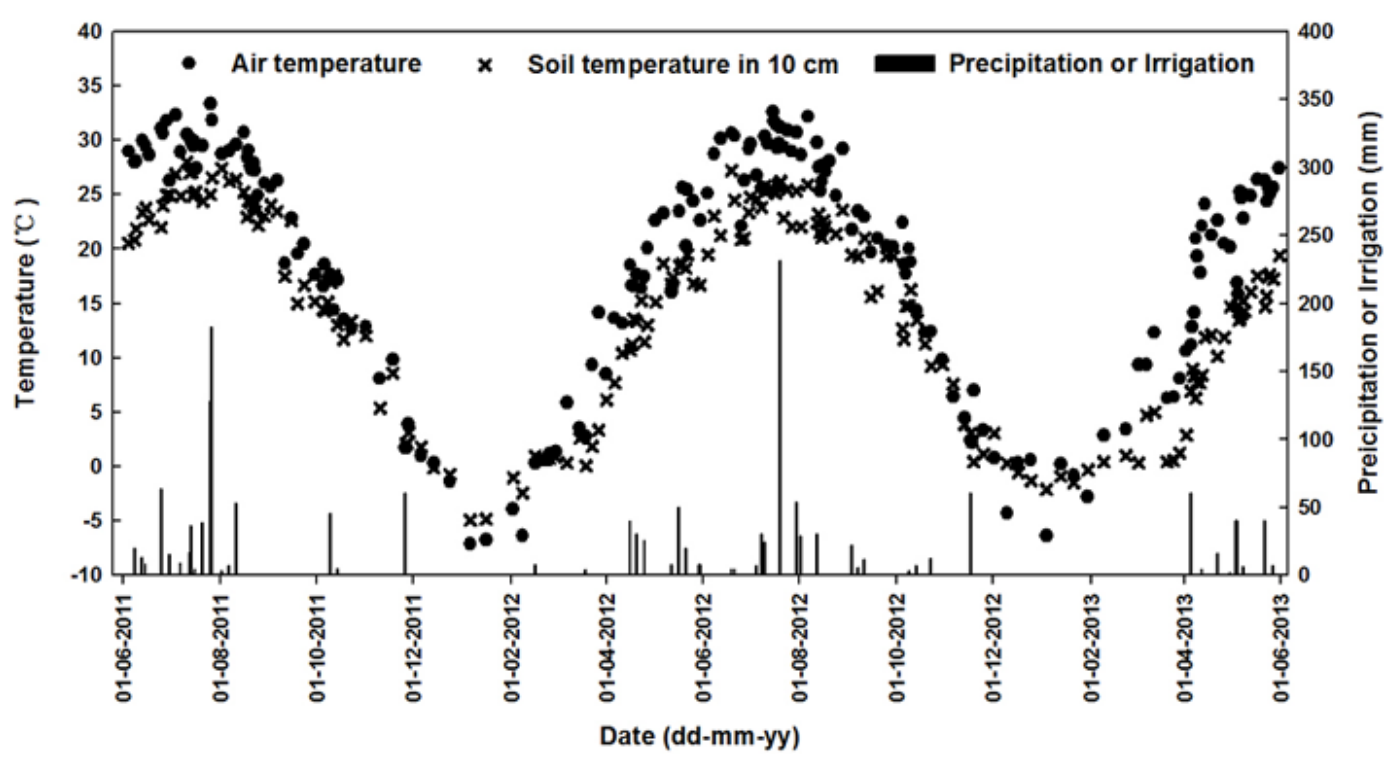

Fig. 1. Air temperature, soil temperature at $10 \mathrm{~cm}$ depth, and precipitation or irrigation in the winter wheat-summer maize double-cropping system from June 2011 to June 2013.

\subsection{Topsoil SOC measurement}

Soil samples were taken to a depth of $20 \mathrm{~cm}$ from each plot before summer maize harvest to determine the SOC content. Each sample was a composite of five subsamples which were taken randomly from each plot. Samples were passed through a $2 \mathrm{~mm}$ sieve and visible plant residues were removed after air drying. The SOC content was determined with a $\mathrm{CN}$ analyser (Vario Max CN, Elementar, Hanau, Germany) after soaking for 24 hours in excess of $0.3 \mathrm{~mol} \mathrm{~L}^{-1}$ $\mathrm{HCl}$ solution to remove calcium carbonate $\left(\mathrm{CaCO}_{3}\right)$ and oven-drying at $65^{\circ} \mathrm{C}$. We also measured the topsoil $(0$ $20 \mathrm{~cm}$ ) bulk density by the cutting-ring method annually after the maize harvest. Because the changes in SOC content at the depths of 20-40 and 40-60 cm were very small over the last 6 years and not significantly different between treatments, we calculated the SOC content in the different treatments only in the top $20 \mathrm{~cm}$ of the soil profile.

The topsoil SOC content $\left(\mathrm{g} \mathrm{kg}^{-1}\right)$ increased annually during the period 2006-2012 in all treatments except $\mathrm{N}_{0}$ (Fig. 2). Linear regression was therefore used to simulate the annual rate of increase of SOC content for all treatments:

$\mathrm{SOC}=a t+b$,

where $t$ is the duration of the experiment (years since 2006). Annual topsoil organic carbon sequestration rate $\left(\mathrm{SOC}_{\mathrm{SR}}, \mathrm{kg}\right.$ $\mathrm{Cha}^{-1} \mathrm{yr}^{-1}$ ) was estimated on the basis of the rate of increase of topsoil SOC content $\left(d_{\mathrm{SOC}} / d_{\mathrm{t}}, \mathrm{g} \mathrm{C} \mathrm{kg}^{-1} \mathrm{yr}^{-1}\right)$. Based on Eq. (1), $d_{\mathrm{SOC}} / d_{\mathrm{t}}$ was estimated by a. Therefore, $\mathrm{SOC}_{\mathrm{SR}}$ was estimated using the following equation:

$\mathrm{SOC}_{\mathrm{SR}}=a \times B \times 20 \times 100$, where $B$ is the bulk density $\left(\mathrm{g} \mathrm{cm}^{-3}\right)$ of the topsoil $(0-$ $20 \mathrm{~cm}$ ). The numbers 20 and 100 in the equation are the topsoil depth and the area conversion coefficient, respectively. Similarly, the $\mathrm{SOC}_{\text {density }}\left(\mathrm{Mg} \mathrm{Cha}^{-1}\right)$ was calculated by

$\mathrm{SOC}_{\text {density }}=c \times B \times 20 / 10$,

where $c$ and $B$ are the SOC content and bulk density of the topsoil $(0-20 \mathrm{~cm})$, respectively. The numbers 20 and 10 in the equation are the topsoil depth and the area conversion coefficient, respectively.

\subsection{Plant measurement}

The above-ground biomass was measured in the middle of each plot at the winter wheat harvest within an area of $9 \mathrm{~m}^{2}$ $(3 \mathrm{~m} \times 3 \mathrm{~m})$. Grain and straw samples were oven-dried at $65^{\circ} \mathrm{C}$ until constant weight to determine dry matter yield. In the case of summer maize $14.4 \mathrm{~m}^{2}$ (six rows $4 \mathrm{~m}$ in length) in the middle of each plot were harvested to determine the fresh ear and stover yields together with ear number. Five plants were randomly sampled from the harvested summer maize and separated into grains, cobs and stover to determine the oven-dried weight at $65^{\circ} \mathrm{C}$. The grain yield of maize was estimated by deduction of cob yield. The $\mathrm{C}$ content in straw was determined using a $\mathrm{CN}$ analyser (Vario Max CN, Elementar, Hanau, Germany).

\section{$2.6 \quad \mathrm{~N}_{2} \mathrm{O}$ emission measurements}

$\mathrm{N}_{2} \mathrm{O}$ emissions were measured manually in two cycles of winter wheat-summer maize from 2011 to 2013 using the closed static chamber method (Mosier et al., 2006). Before the wheat was sown, two types of base collar 
(length $\times$ width $=60 \mathrm{~cm} \times 50 \mathrm{~cm}$ and $60 \mathrm{~cm} \times 30 \mathrm{~cm}$ ) made of stainless steel were inserted $20 \mathrm{~cm}$ into the soil in every plot. These collars were removed only once per year before tillage after summer maize harvest and remained in position during the whole crop rotation. Type I chambers (length $\times$ width $\times$ height $=60 \mathrm{~cm} \times 50 \mathrm{~cm} \times 50 \mathrm{~cm}$ ) were designed to measure $\mathrm{N}_{2} \mathrm{O}$ emissions from the winter wheat season and early stages of summer maize (before $50 \mathrm{~cm}$ height). The two parts of type I chambers were sealed by a groove filled with water on the top edge of the base collar. If the maize height surpassed $50 \mathrm{~cm}$, type II chambers (length $\times$ width $\times$ height $=60 \mathrm{~cm} \times 30 \mathrm{~cm} \times 20 \mathrm{~cm}$ ) were used, separated vertically into two parts and with a hole $(11 \mathrm{~cm}$ diameter) drilled in the centre of the top of the chamber (Liu et al., 2012). Type II chambers allowed the cornstalks to pass through the chamber tops, and as a result only the maize roots were covered. The gaps between the type II chambers and cornstalks were sealed using a preservative film $(1.2 \mu \mathrm{m}$-thick polyvinylidene chloride) when the chambers were closed. The two parts of type II chambers were sealed with rubber. Each chamber was covered with a layer of insulating material to minimize any chamber effects on air temperature to $<3{ }^{\circ} \mathrm{C}$ in the headspace during gas sampling, and the interior of the chamber was equipped with two opposing ventilators to ensure complete mixing of air. The first sample was collected immediately from the chamber roof after the chamber was enclosed. Four gas samples were collected at intervals of $15 \mathrm{~min}$ using $50 \mathrm{~mL}$ plastic injectors through a three-way stopcock and a Teflon tube connected to the chamber. Daily measurements were carried out for about 10 days and 5 days after fertilizer application and rainfall or irrigation, respectively, for the remaining periods emissions were measured twice per week and once a week when the soil was frozen (Hu et al., 2013). The sampling time was between 08:00 and 11:00 a.m. of the local time.

Gas samples were analysed for $\mathrm{N}_{2} \mathrm{O}$ using a modified gas chromatograph (GC; Agilent 6820, USA) equipped with a ${ }^{63} \mathrm{Ni}$-electron capture detector (ECD) running at $350{ }^{\circ} \mathrm{C}$. High-purity dinitrogen $\left(\mathrm{N}_{2}, 99.999 \%\right)$ was used as the carrier gas for $\mathrm{N}_{2} \mathrm{O}$ analysis and $10 \% \mathrm{CO}_{2}$ in pure $\mathrm{N}_{2}$ as a makeup gas for ECD (Zheng et al., 2008). The detection limits of the GC were $2 \mu \mathrm{g} \mathrm{N} \mathrm{m}{ }^{-2} \mathrm{~h}^{-1}$ for $\mathrm{N}_{2} \mathrm{O}$ at a chamber height of $50 \mathrm{~cm}$. The $\mathrm{GC}$ was calibrated using known concentrations of mixed gas $\left(0.354 \mathrm{ppm} \mathrm{N}_{2} \mathrm{O}\right.$ in pure $\left.\mathrm{N}_{2}\right)$ which was calibrated using standard calibration gases during each group measurement cycle, and air conditioning was used for temperature stabilization during measurement in the laboratory to minimize the tendency of the ECD to drift with changing temperature.

Taking into account the methodology for calculating the fluxes of $\mathrm{N}_{2} \mathrm{O}$ emissions from some previous studies, the $\mathrm{N}_{2} \mathrm{O}$ fluxes were calculated by linear regression (Eq. 5) or nonlinear (Eq. 6) methods according to the changing pattern of gas concentration in the headspace of the closed chamber
(Livingston et al., 2005; Kroon et al., 2008). The flux of $\mathrm{N}_{2} \mathrm{O}$ emission $\left(\mu \mathrm{g} \mathrm{N}_{2} \mathrm{O}-\mathrm{N} \mathrm{ha}^{-1} \mathrm{~d}^{-1}\right)$ was calculated as

$F=k_{1} \times P_{0} / P \times 273 /(273+T) \times 28 / 22.4 \times 0.5 \times \mathrm{d} c / \mathrm{d} t$

$c=a+b t(\mathrm{~d} c / \mathrm{d} t=b)$,

$c=a+b t+\mathrm{d} t^{2}(\mathrm{~d} c / \mathrm{d} t=b)$,

where $F\left(\mu \mathrm{g} \mathrm{N} \mathrm{N}_{2} \mathrm{O}-\mathrm{N} \mathrm{m}^{-2} \mathrm{~h}^{-1}\right)$ is the flux; $k_{1}$ is a coefficient $(0.001)$ for dimensional conversion; $P_{0}$ is air pressure incubation $(\mathrm{hPa}) ; P$ is the ambient air pressure at the experimental site $(1013 \mathrm{hPa}) ; P_{0} / P \approx 1$ because the altitude of the experimental site is $40 \mathrm{~m}$ and very close to sea level; $T\left({ }^{\circ} \mathrm{C}\right)$ is mean air temperature in the chamber; $28\left(\mathrm{~g} \mathrm{~N}_{2} \mathrm{O}-\mathrm{N} \mathrm{mol}^{-1}\right)$ is the molecular weight of $\mathrm{N}_{2}$ in the $\mathrm{N}_{2} \mathrm{O}$ molecule; 22.4 $\left(\mathrm{L} \mathrm{mol}^{-1}\right)$ is the molecular volume at $1,013 \mathrm{hPa}$ and $273 \mathrm{~K}$; $0.5(\mathrm{~m})$ is the chamber height; $c(\mathrm{ppm})$ is the concentration of $\mathrm{N}_{2} \mathrm{O} ; t(\mathrm{~h})$ is the time of chamber closure; and $\mathrm{dc} / \mathrm{dt}$ $\left(\mu \mathrm{LL}^{-1} \mathrm{~h}^{-1}\right)$ is the rate of increase in $\mathrm{N}_{2} \mathrm{O}$ concentration in the chamber (Zheng et al., 2008). $P_{0} / P \times 273 /(273+T$ ) is the temperature- and pressure-corrected mole volume. $\mathrm{d} c / \mathrm{d} t$ is the slope of the curve which was calculated depending on the pattern of the concentration changes in the headspace (Kroon et al., 2008), and $a, b$ and $d$ are constants. $\mathrm{N}_{2} \mathrm{O}$ emissions are the mean values of three replicates on the sampling days. The seasonal or annual cumulative $\mathrm{N}_{2} \mathrm{O}$ emissions were estimated from the sum of measurement and nomeasurement days, which was estimated by linear interpolation (Mosier et al., 2006).

\subsection{NGWP and GHGI calculation}

To better understand climatic effects of the nitrogen and straw management on winter wheat-summer maize doublecropping system, the NGWP and GHGI were calculated using the following equations.

$\mathrm{N}_{2} \mathrm{O}_{\mathrm{GWP}}=\mathrm{N}_{2} \mathrm{O}\left(\mathrm{kgN}_{2} \mathrm{O}-\mathrm{Nha}^{-1}\right) / 28 \times 44 \times 298$,

where 28 is the molecular weight of $\mathrm{N}$ in $\mathrm{N}_{2} \mathrm{O}$ and 44 is the molecular weight of $\mathrm{N}_{2} \mathrm{O}$. The global warming potentials of $1 \mathrm{~kg} \mathrm{~N} \mathrm{~N}_{2} \mathrm{O}$ is equivalent to $298 \mathrm{~kg} \mathrm{CO}_{2}$ based on 100 years (IPCC, 2007).

$\mathrm{CH}_{4 \mathrm{GWP}}=\mathrm{CH}_{4}\left(\mathrm{kgCH}_{4}-\mathrm{Cha}^{-1}\right) / 12 \times 16 \times 25$,

where 12 is the molecular weight of $\mathrm{C}$ in $\mathrm{CH}_{4}$ and 16 is the molecular weight of $\mathrm{CH}_{4}$. The global warming potential of $1 \mathrm{~kg} \mathrm{CH}_{4}$ is equivalent to $25 \mathrm{~kg} \mathrm{CO}_{2}$ based on 100 years (IPCC, 2007). We adopted $\mathrm{CH}_{4}$ uptake by $1 \mathrm{~kg} \mathrm{CH}_{4}$ $\mathrm{Cha}^{-1} \mathrm{yr}^{-1}$, the result from two continuous years of study 


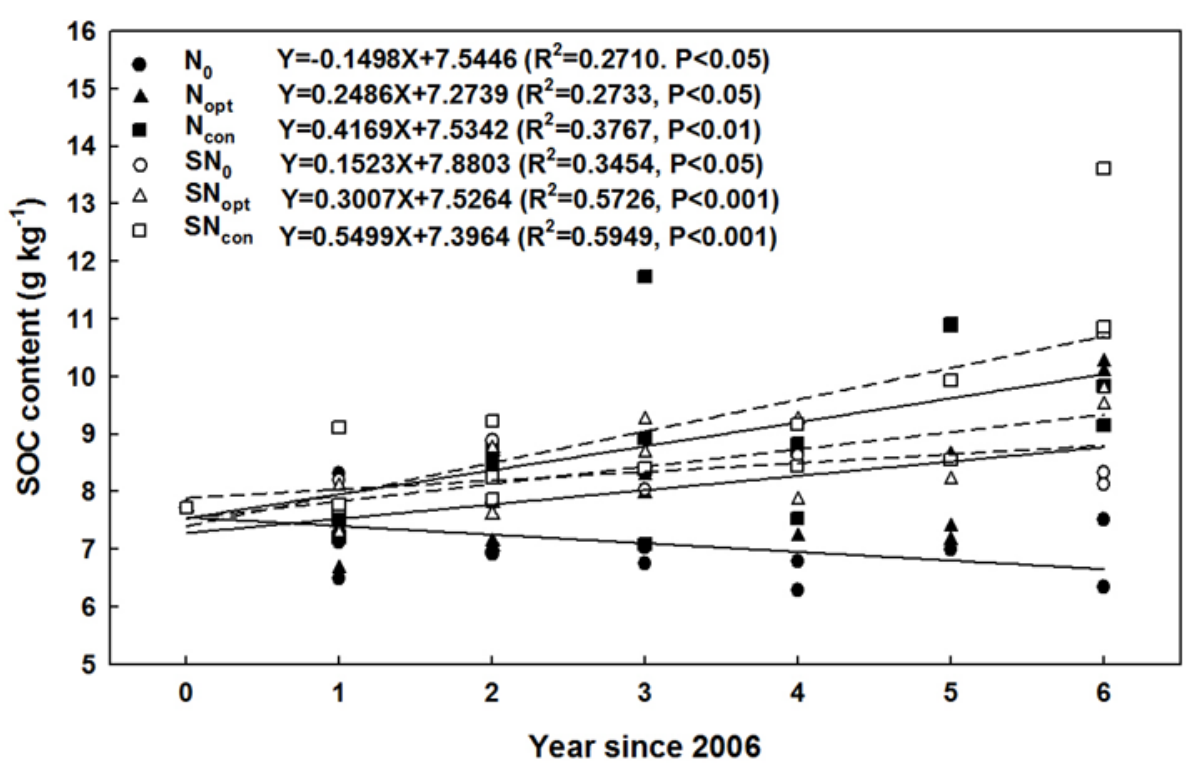

Fig. 2. Changes in soil organic carbon (SOC) in the top $20 \mathrm{~cm}$ of the soil profile in the winter wheat-summer maize double-cropping system from 2006 to 2012. The dashed line and solid line were fitted by linear regression from straw and without straw treatments, respectively.

using the same cropping system and climatic zone (Hu et al., 2013).

$\operatorname{SOC}_{\mathrm{GWP}}=\operatorname{SOC}_{\mathrm{SR}}\left(\mathrm{kgCha}^{-1}\right) / 12 \times 44$,

where the 12 is the molecular weight of $\mathrm{C}$ in $\mathrm{CO}_{2}$ and 44 is the molecular weight of $\mathrm{CO}_{2}$.

$$
\begin{aligned}
\text { Fertilizer }_{\text {GWP }}= & \text { N rate }\left(\mathrm{kg} \mathrm{Nha} \mathrm{ha}^{-1}\right) \times 8.3+P_{2} \mathrm{O}_{5} \text { rate } \\
& \left(\mathrm{kg} \mathrm{P}_{2} \mathrm{O}_{5} \mathrm{ha}^{-1}\right) \times 1.51+K_{2} \mathrm{Orate} \\
& \left(\mathrm{kg} \mathrm{K} \mathrm{Oha}_{2} \mathrm{Oha}^{-1} \times 0.98,\right.
\end{aligned}
$$

where the 8.3, 1.51 and 0.98 are the GHG emissions $(\mathrm{kg}$ $\mathrm{CO}_{2}$-eq kg ${ }^{-1}$ ) associated with the manufacture and transportation of fertilizer $N$ (Zhang et al., 2013), $P$ and $K$ (Huang et al., 2011), respectively. The date, type and rate of fertilizer applications were recorded in detail.

Power $_{\mathrm{GWP}}=$ Electricity $(\mathrm{kW}) \times$ time $(\mathrm{h}) \times 1.30$,

where $1.30\left(\mathrm{~kg} \mathrm{CO}_{2}\right.$-eq $\left.(\mathrm{kWh})^{-1}\right)$ is the GHG emission $(\mathrm{kg}$ $\mathrm{CO}_{2}$-eq kg${ }^{-1}$ ) associated with the production and utilization of electricity by coal combustion (Zhang et al., 2013). The duration of every irrigation event and the pump power consumption were recorded in detail. The electricity consumption for irrigation was sum of the duration of all irrigation events multiplied by the power of the pump.

Fuel $_{\mathrm{GWP}}=$ Diesel oil $(\mathrm{L}) \times 3.94$,

where $3.94\left(\mathrm{~kg} \mathrm{CO}_{2}\right.$-eq L $\left.{ }^{-1}\right)$ is the $\mathrm{GHG}$ emission $(\mathrm{kg}$ $\mathrm{CO}_{2}$-eq kg${ }^{-1}$ ) associated with diesel oil combustion (Huang et al., 2011). The energy consumption of every farm machinery operation was recorded in detail. The annual consumption of diesel oil by farm machinery operations was 64 and
$70 \mathrm{~L} \mathrm{ha}^{-1}$ from the straw removal and return treatments, respectively.

Pesticide $_{\mathrm{GWP}}=$ Pesticide $(\mathrm{kg}) \times 18.0$,

where $18.0\left(\mathrm{~kg} \mathrm{CO}_{2}\right.$-eq kg$\left.{ }^{-1}\right)$ is the GHG emission $(\mathrm{kg}$ $\mathrm{CO}_{2}$-eq kg ${ }^{-1}$ ) associated with pesticide production (Huang et al., 2011). The dates, types and rates of pesticide application were recorded in detail. The annual consumption of pesticide was $6.2 \mathrm{~kg} \mathrm{ha}^{-1}$.

$$
\begin{aligned}
\text { Net-GWP } & =\mathrm{N}_{2} \mathrm{O}_{\mathrm{GWP}}-\mathrm{SOC}_{\mathrm{GWP}}-\mathrm{CH}_{4 \mathrm{GWP}} \\
& + \text { Fertilizer }_{\mathrm{GWP}}+\text { Power }_{\mathrm{GWP}}+\text { Fuel }_{\mathrm{GWP}}
\end{aligned}
$$

GHGI $=$ Net-GWP/grain yield

The units of NGWP and GHGI are $\mathrm{kg} \mathrm{CO}_{2}$-eq ha ${ }^{-1} \mathrm{yr}^{-1}$ and $\mathrm{kg} \mathrm{CO}_{2}$-eq $\mathrm{Mg}^{-1} \mathrm{yr}^{-1}$ grain, respectively.

\subsection{Statistical analysis}

The primary data were examined using Microsoft Excel spreadsheets. The grain yield, seasonal and annual $\mathrm{N}_{2} \mathrm{O}$ emissions and SOC density of the different treatments were tested by analysis of variance and mean values were compared by least significant difference (LSD) at the $5 \%$ level using the SAS statistical software package (version 8.2; SAS Institute, Inc., Cary, NC). 
Table 2. Fertilizer $\mathrm{N}$ rates $\left(\mathrm{kg} \mathrm{N} \mathrm{ha}^{-1}\right)$ in the winter wheat-summer maize cropping system from October 2006 to September 2012.

\begin{tabular}{|c|c|c|c|c|c|c|c|c|c|c|c|c|c|c|}
\hline \multirow[t]{2}{*}{ Treatments $^{\mathrm{a}}$} & \multicolumn{2}{|c|}{$2006-2007$} & \multicolumn{2}{|c|}{$2007-2008$} & \multicolumn{2}{|c|}{$2008-2009$} & \multicolumn{2}{|c|}{$2009-2010$} & \multicolumn{2}{|c|}{$2010-2011$} & \multicolumn{2}{|c|}{$2011-2012$} & \multicolumn{2}{|c|}{ Mean of six years } \\
\hline & $W^{b}$ & SM & WW & SM & WW & SM & WW & SM & WW & SM & WW & SM & WW & SM \\
\hline $\mathrm{N}_{0}$ & 0 & 0 & 0 & 0 & 0 & 0 & 0 & 0 & 0 & 0 & 0 & 0 & 0 & 0 \\
\hline $\mathrm{N}_{\text {opt }}$ & 86 & 45 & 139 & 132 & 127 & 130 & 150 & 30 & 110 & 212 & 150 & 130 & 127 & 113 \\
\hline $\mathrm{N}_{\text {con }}$ & 300 & 260 & 300 & 260 & 300 & 260 & 300 & 260 & 300 & 260 & 300 & 260 & 300 & 260 \\
\hline $\mathrm{SN}_{0}$ & 0 & 0 & 0 & 0 & 0 & 0 & 0 & 0 & 0 & 0 & 0 & 0 & 0 & 0 \\
\hline $\mathrm{SN}_{\mathrm{opt}}$ & 126 & 93 & 181 & 151 & 114 & 132 & 150 & 30 & 107 & 159 & 150 & 130 & 138 & 116 \\
\hline $\mathrm{SN}_{\text {con }}$ & 300 & 260 & 300 & 260 & 300 & 260 & 300 & 260 & 300 & 260 & 300 & 260 & 300 & 260 \\
\hline
\end{tabular}

standard error $(n=3)$; $\mathrm{N}$ application in 2006-2009 was retrieved from Qiu et al. (2012).

Table 3. Grain yield (dry matter, $\mathrm{Mg} \mathrm{ha}^{-1}$ ) in winter wheat-summer maize double-cropping system from October 2010 to October 2012.

\begin{tabular}{|c|c|c|c|c|c|c|c|c|}
\hline \multicolumn{2}{|c|}{ Treatments $^{\mathrm{a}}$} & \multirow{2}{*}{$\begin{array}{l}\text { 2010-2011 } \\
\text { WW }^{\mathrm{b}}\end{array}$} & \multirow{2}{*}{$\begin{array}{l}2011 \\
\text { SM }\end{array}$} & \multirow{2}{*}{$\begin{array}{l}\text { 2010-2011 } \\
\text { Annual yield }\end{array}$} & \multirow{2}{*}{$\begin{array}{l}\text { 2011-2012 } \\
\text { WW }\end{array}$} & \multirow{2}{*}{$\begin{array}{l}2012 \\
\text { SM }\end{array}$} & \multirow{2}{*}{$\begin{array}{l}\text { 2011-2012 } \\
\text { Annual yield }\end{array}$} & \multirow{2}{*}{$\begin{array}{l}\text { 2010-2012 } \\
\text { Mean annual yield }\end{array}$} \\
\hline Nitrogen & Straw & & & & & & & \\
\hline \multicolumn{9}{|c|}{ Treatment effect $(n=3)$} \\
\hline $\mathrm{N}_{0}$ & & $2.67 \pm 0.38 b^{\mathrm{c}}$ & $5.43 \pm 0.40 b$ & $8.10 \pm 0.63 c$ & $2.39 \pm 0.31 b$ & $3.94 \pm 0.35 c$ & $6.33 \pm 0.63 b$ & $7.21 \pm 0.14 b$ \\
\hline $\mathrm{N}_{0}$ & $\mathrm{~S}$ & $2.86 \pm 0.44 b$ & $4.99 \pm 0.33 b$ & $7.86 \pm 0.70 c$ & $2.50 \pm 0.36 b$ & $4.48 \pm 0.59 c$ & $6.98 \pm 0.95 b$ & $7.42 \pm 0.74 b$ \\
\hline $\mathrm{N}_{\mathrm{opt}}$ & & $5.40 \pm 0.59 a$ & $6.52 \pm 0.84 \mathrm{ab}$ & $11.92 \pm 1.11 \mathrm{ab}$ & $4.27 \pm 0.61 a$ & $6.08 \pm 0.31 b$ & $10.35 \pm 0.91 a$ & $11.14 \pm 0.92 a$ \\
\hline $\mathrm{N}_{\mathrm{opt}}$ & $\mathrm{S}$ & $5.35 \pm 0.23 a$ & $5.94 \pm 0.73 b$ & $11.29 \pm 0.87 b$ & $4.70 \pm 0.37 a$ & $6.46 \pm 0.36 \mathrm{ab}$ & $11.16 \pm 0.60 a$ & $11.23 \pm 0.60 a$ \\
\hline $\mathrm{N}_{\text {con }}$ & & $5.51 \pm 0.11 a$ & $6.49 \pm 1.11 \mathrm{ab}$ & $12.00 \pm 1.14 \mathrm{ab}$ & $4.53 \pm 0.42 a$ & $7.29 \pm 0.36 a$ & $11.82 \pm 0.78 a$ & $11.91 \pm 0.73 a$ \\
\hline $\mathrm{N}_{\text {con }}$ & $\mathrm{S}$ & $5.65 \pm 0.80 a$ & $7.85 \pm 0.27 a$ & $13.50 \pm 0.89 a$ & $4.58 \pm 0.41 a$ & $7.30 \pm 0.26 a$ & $11.88 \pm 0.67 a$ & $12.69 \pm 0.75 a$ \\
\hline \multicolumn{9}{|c|}{ Nitrogen effect $(n=6)$} \\
\hline & mean & $2.77 \pm 0.27 b$ & $5.21 \pm 0.17 b$ & $7.98 \pm 0.35 b$ & $2.44 \pm 0.32 b$ & $4.21 \pm 0.47 c$ & $6.65 \pm 0.78 c$ & $7.32 \pm 0.40 c$ \\
\hline & tmean & $5.38 \pm 0.27 a$ & $6.23 \pm 0.53 \mathrm{ab}$ & $11.61 \pm 0.56 a$ & $4.49 \pm 0.16 a$ & $6.27 \pm 0.21 b$ & $10.76 \pm 0.37 b$ & $11.18 \pm 0.19 b$ \\
\hline & nmean & $5.58 \pm 0.35 a$ & $7.17 \pm 0.43 a$ & $12.75 \pm 0.66 a$ & $4.55 \pm 0.41 a$ & $7.30 \pm 0.31 a$ & $11.85 \pm 0.72 a$ & $12.30 \pm 0.66 a$ \\
\hline \multicolumn{9}{|c|}{ Straw effect $(n=9)$} \\
\hline With & ut straw & $4.53 \pm 0.12 a$ & $6.15 \pm 0.23 a$ & $10.67 \pm 0.12 a$ & $3.73 \pm 0.41 a$ & $5.77 \pm 0.32 a$ & $9.50 \pm 0.73 a$ & $10.09 \pm 0.31 a$ \\
\hline & straw & $4.62 \pm 0.32 a$ & $6.26 \pm 0.26 a$ & $10.88 \pm 0.26 a$ & $3.93 \pm 0.16 a$ & $6.08 \pm 0.31 a$ & $10.01 \pm 0.46 a$ & $10.44 \pm 0.25 a$ \\
\hline
\end{tabular}

\section{Results}

\subsection{N Fertilizer rate and grain yield}

The optimum $\mathrm{N}$ management $\left(\mathrm{N}_{\text {opt }}\right.$ and $\left.\mathrm{SN}_{\text {opt }}\right)$ with the improved Nmin test significantly reduced $\mathrm{N}$ fertilizer rate to both crops compared to conventional farming practice $\left(\mathrm{N}_{\text {con }}\right.$ $\& \mathrm{SN}_{\mathrm{con}}$ ), which saved 54-58, 56-57 and 55-57\% $\mathrm{N}$ fertilizer in winter wheat, summer maize and annually, respectively (Table 2). Application of $\mathrm{N}\left(\mathrm{N}_{\mathrm{opt}}\right.$ and $\left.\mathrm{N}_{\mathrm{con}}\right)$ significantly increased the grain yield by $20-94$ and $38-101 \%$, respectively, compared to the control, but there was no significant difference between $\mathrm{N}_{\text {opt }}$ and $\mathrm{N}_{\text {con }}$ except in maize in 2012 (Table 3). Although there was almost 3.7-5.5 Mg $\mathrm{Cha}^{-1} \mathrm{yr}^{-1}$ straw input in treatments $\mathrm{SN}_{0}, \mathrm{SN}_{\text {opt }}$ and $\mathrm{SN}_{\text {con }}$, the yields increased by only $1.8-5.4 \%$ over the two years (four crops) compared to the straw removal treatments.

\subsection{Changes in topsoil SOC content and density}

The significantly changes in SOC densities in all treatments were only found in $0-20 \mathrm{~cm}$, but not in $20-40$ and $40-60 \mathrm{~cm}$ in 2012 (Table 4). Compared to the $\mathrm{N}_{0}$ treat- ment, long-term $\mathrm{N}$ application and straw return gradually increased topsoil SOC content by $2.9-51.9 \%$ (Fig. 2). The topsoil SOC content rate of increase was in the sequence $\mathrm{SN}_{\text {con }}\left(0.55 \mathrm{~g} \mathrm{~kg}^{-1} \mathrm{yr}^{-1}\right)>\mathrm{N}_{\text {con }}\left(0.42 \mathrm{~g} \mathrm{~kg}^{-1} \mathrm{yr}^{-1}\right)>\mathrm{SN}_{\text {opt }}$ $\left(0.30 \mathrm{~g} \mathrm{~kg}^{-1} \mathrm{yr}^{-1}\right)>\mathrm{N}_{\text {opt }} \quad\left(0.25 \mathrm{~g} \mathrm{~kg}^{-1} \mathrm{yr}^{-1}\right)>\mathrm{SN}_{0} \quad(0.15$ $\mathrm{g} \mathrm{kg}^{-1} \mathrm{yr}^{-1}$ ), but with $\mathrm{N}_{0}$ decreasing by $0.15 \mathrm{~g} \mathrm{~kg}^{-1} \mathrm{yr}^{-1}$.

In 2012 the topsoil SOC density of $\mathrm{SN}_{\text {con }}$ was the highest and was significantly higher than the other treatments (Table 4), and those of $\mathrm{SN}_{\text {con }}, \mathrm{N}_{\text {con }}, \mathrm{SN}_{\text {opt }}$ and $\mathrm{N}_{\text {opt }}$ were significantly higher than the $\mathrm{N}_{0}$ treatment. As for the nitrogen application effect, $\mathrm{N}_{\text {con }}$ was the highest and was 4.5-13.9\% and $2.0-23.3 \%$ higher than $\mathrm{N}_{\text {opt }}$ and $\mathrm{N}_{0}$, respectively. The differences among the three $\mathrm{N}$ levels were not significant until 2012, when $\mathrm{N}_{\text {con }}$ and $\mathrm{N}_{\text {opt }}$ were significantly higher than $\mathrm{N}_{0}$ $(P<0.05)$. As for the straw return effect, the $0-20 \mathrm{~cm}$ SOC density from straw return was $20.1-26.1 \mathrm{Mg} \mathrm{Cha}^{-1}$ across 6 years, which was 3.9-16.5\% higher than without straw, but there were no significantly differences between straw return and straw removal over the 6 yr period. 


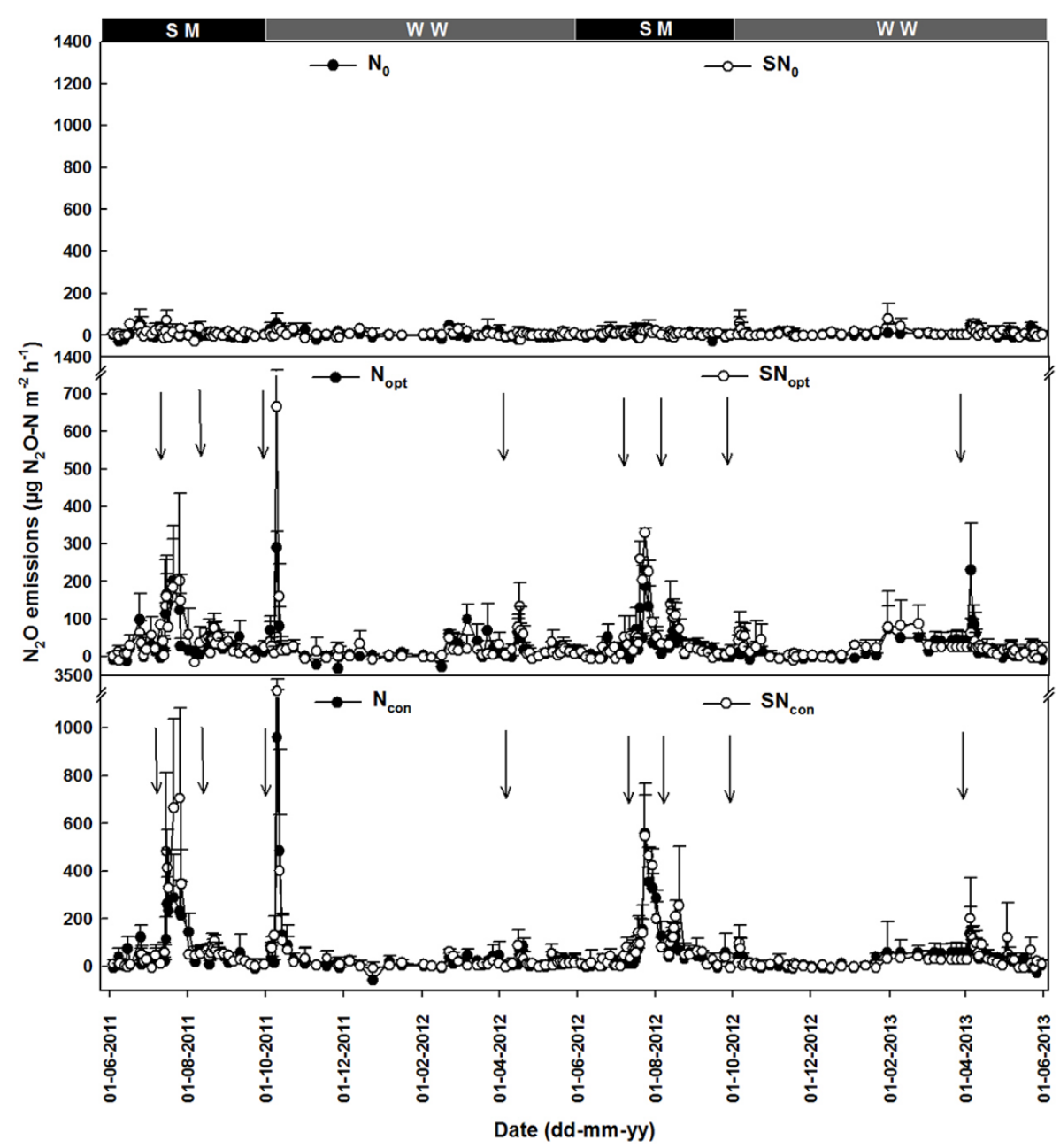

Fig. 3. Nitrous oxide $\left(\mathrm{N}_{2} \mathrm{O}\right)$ fluxes in the winter wheat-summer maize double-cropping system from June 2011 to June 2013 . The arrows show the dates of fertilizer $\mathrm{N}$ application.

\section{3 $\quad \mathrm{N}_{2} \mathrm{O}$ emissions}

The patterns of $\mathrm{N}_{2} \mathrm{O}$ fluxes from June 2011 to June 2013 are shown in Fig. 3 for all treatments. The fluxes of the all plots varied from -28.3 to $1682.1 \mu \mathrm{g} \mathrm{N}_{2} \mathrm{O}-\mathrm{N} \mathrm{m}^{-2} \mathrm{~h}^{-1}$. Several $\mathrm{N}_{2} \mathrm{O}$ emission peaks were observed in the fertilized treatments, which were associated with $\mathrm{N}$ fertilizer application events coupled with irrigation/rainfall or tillage or triggered by heavy rainfall alone, and two may have been related to the freeze-thaw effect on 20 March 2012 and 15 March 2013, when the soil temperature increased above $0^{\circ} \mathrm{C}$. Fertilization alone only slightly stimulated $\mathrm{N}_{2} \mathrm{O}$ emissions within two weeks, i.e. the maximum $\mathrm{N}_{2} \mathrm{O}$ emissions amounting to 106.9, 254.8 and $82.2 \mu \mathrm{g} \mathrm{N} \mathrm{N}_{2} \mathrm{O}-\mathrm{N} \mathrm{m}^{-2} \mathrm{~h}^{-1}$ after fertilization at the ten-leaf stage of 2011 maize, 2012 maize and basal fertilization in 2012-2013 wheat, respectively. When fertilization was coupled with rainfall or irrigation, massive pulses of $\mathrm{N}_{2} \mathrm{O}$ emissions were observed, with maximum fluxes up to $230.2 \mu \mathrm{g} \mathrm{N} \mathrm{N}_{2} \mathrm{O}-\mathrm{N} \mathrm{m}^{-2} \mathrm{~h}^{-1}$ at shooting stage in 2012-2013 wheat, and 704.7, $556.1 \mu \mathrm{g} \mathrm{N} \mathrm{N}_{2} \mathrm{O}-\mathrm{N} \mathrm{m}^{-2} \mathrm{~h}^{-1}$ after four-leaf stage fertilization in 2011 and 2012 maize. The highest $\mathrm{N}_{2} \mathrm{O}$ emission was $1682.1 \mu \mathrm{g} \mathrm{N} \mathrm{N}_{2} \mathrm{O}-\mathrm{N} \mathrm{m}^{-2} \mathrm{~h}^{-1}$ after the wheat was sown in October 2011 because fertilization and tillage were coupled with irrigation.

Annual cumulative $\mathrm{N}_{2} \mathrm{O}$ emissions over the two cropping rotations ranged from 0.20 to 4.54 and 0.47 to $4.35 \mathrm{~kg} \mathrm{~N}_{2} \mathrm{O}$ $\mathrm{N} \mathrm{ha}^{-1}$ in 2011-2012 and 2012-2013, respectively (Table 5). The seasonal cumulative $\mathrm{N}_{2} \mathrm{O}$ emission from all treatments was in the order $\mathrm{SN}_{\text {con }}>\mathrm{N}_{\text {con }}>\mathrm{SN}_{\text {opt }}>\mathrm{N}_{\mathrm{opt}}>\mathrm{SN}_{0}>\mathrm{N}_{0}$ in these four different seasons. As for the nitrogen application effect, annual cumulative $\mathrm{N}_{2} \mathrm{O}$ emissions in $\mathrm{N}_{\text {opt }}$ and $\mathrm{N}_{\text {con }}$ were significantly higher than $\mathrm{N}_{0}(P<0.05)$, with increases of more than 3 and 6 times, respectively. The cumulative $\mathrm{N}_{2} \mathrm{O}$ emissions of $\mathrm{N}_{\text {con }}$ in 2011-2012 and 2012-2013 winter wheat were not significantly higher than $\mathrm{N}_{\mathrm{opt}}$, but the opposite trend occurred in 2011 and 2012 summer maize. As for the straw return effect, the seasonal cumulative $\mathrm{N}_{2} \mathrm{O}$ emissions from the straw return treatments increased by 36,28 , 
Table 4. Soil organic carbon (SOC) density $\left(\mathrm{Mg} \mathrm{Cha}^{-1}\right)$ in 0-20, 20-40, 40-60 $\mathrm{cm}$ in winter wheat-summer maize double-cropping system for the year 2006 and 2012.

\begin{tabular}{|c|c|c|c|c|c|c|c|}
\hline \multicolumn{2}{|c|}{ Treatment $^{\mathrm{a}}$} & \multicolumn{2}{|c|}{$0-20 \mathrm{~cm}$} & \multicolumn{2}{|c|}{$20-40 \mathrm{~cm}$} & \multicolumn{2}{|c|}{$40-60 \mathrm{~cm}$} \\
\hline Nitrogen & Straw & 2006 & 2012 & 2006 & 2012 & 2006 & 2012 \\
\hline \multicolumn{8}{|c|}{ Treatment effect $(n=3)$} \\
\hline $\mathrm{N}_{0}$ & & 20.2 & $18.1 \pm 1.2 c^{\mathrm{b}}$ & 19.6 & $17.2 \pm 0.9 a$ & 16.6 & $15.1 \pm 0.8 a$ \\
\hline $\mathrm{N}_{0}$ & $\mathrm{~S}$ & 20.2 & $22.2 \pm 1.3 b c$ & 19.6 & $17.8 \pm 2.7 a$ & 16.6 & $16.5 \pm 0.7 a$ \\
\hline $\mathrm{N}_{\mathrm{opt}}$ & & 20.2 & $24.2 \pm 0.5 b$ & 19.6 & $16.5 \pm 0.5 a$ & 16.6 & $16.0 \pm 1.0 a$ \\
\hline $\mathrm{N}_{\text {opt }}$ & $\mathrm{S}$ & 20.2 & $25.3 \pm 2.9 b$ & 19.6 & $19.4 \pm 3.0 a$ & 16.6 & $16.3 \pm 1.4 a$ \\
\hline $\mathrm{N}_{\text {con }}$ & & 20.2 & $24.9 \pm 3.8 b$ & 19.6 & $19.9 \pm 2.6 a$ & 16.6 & $16.2 \pm 0.3 a$ \\
\hline $\mathrm{N}_{\text {con }}$ & $\mathrm{S}$ & 20.2 & $30.8 \pm 4.3 a$ & 19.6 & $20.7 \pm 3.4 a$ & 16.6 & $16.7 \pm 2.2 a$ \\
\hline \multicolumn{8}{|c|}{ Nitrogen effect $(n=6)$} \\
\hline & mean & 20.2 & $20.2 \pm 2.1 b$ & 19.6 & $17.5 \pm 1.7 a$ & 16.6 & $15.8 \pm 0.5 a$ \\
\hline & tmean & 20.2 & $24.7 \pm 4.0 a$ & 19.6 & $18.0 \pm 1.4 a$ & 16.6 & $16.2 \pm 0.4 a$ \\
\hline & n mean & 20.2 & $27.8 \pm 3.4 a$ & 19.6 & $20.3 \pm 2.6 a$ & 16.6 & $16.4 \pm 1.2 a$ \\
\hline \multicolumn{8}{|c|}{ Straw effect $(n=9)$} \\
\hline With & ut straw & 20.2 & $22.4 \pm 1.3 a$ & 19.6 & $17.9 \pm 1.1 a$ & 16.6 & $15.7 \pm 0.4 a$ \\
\hline Wi & straw & 20.2 & $26.1 \pm 1.7 a$ & 19.6 & $19.3 \pm 2.3 a$ & 16.6 & $16.5 \pm 1.2 a$ \\
\hline
\end{tabular}

${ }^{\text {a }} \mathrm{N}_{0}, \mathrm{~N}_{\text {opt }}$ and $\mathrm{N}_{\text {con }}$ represent zero- $\mathrm{N}$ (control), optimum and conventional $\mathrm{N}$, respectively. $\mathrm{S}$ is straw return. ${ }^{\mathrm{b}}$ Different lowercase letters within same column denote significant differences between treatments $(P<0.05)$.

34 and $37 \%$ compared to straw removal treatments in the four crops, respectively, but only in 2012 maize was the increase significant $(P<0.05)$. The cumulative $\mathrm{N}_{2} \mathrm{O}$ emissions showed pronounced seasonal variation.

Correlations between seasonal cumulative $\mathrm{N}_{2} \mathrm{O}$ emissions and fertilizer $\mathrm{N}$ application rates from straw removal and straw return were also calculated and the seasonal cumulative $\mathrm{N}_{2} \mathrm{O}$ emissions increased linearly with increasing $\mathrm{N}$ application rate (Fig. 4). Compared to the straw removal treatments, the slopes from the straw return treatments were 56,8 , 23 and $10 \%$ higher in 2011 maize, 2011-2012 wheat, 2012 maize and 2012-2013 wheat, respectively.

\subsection{NGWP and GHGI}

Although $\mathrm{N}$ fertilizer and straw return increased annual $\mathrm{N}_{2} \mathrm{O}$ emissions, they also increased SOC sequestration and it is interesting to explore the NGWP and GHGI in this doublecropping system. From the view of carbon footprint, we included GHG emissions associated with all the inputs (fertilization, power, fuel, pesticide) and SOC sequestration expressed as $\mathrm{kg} \mathrm{CO}_{2}$-eq $\mathrm{ha}^{-1} \mathrm{yr}^{-1}$ (Table 6). The NGWP was in the order $\mathrm{N}_{\mathrm{con}}>\mathrm{N}_{0}>\mathrm{SN}_{\mathrm{con}}>\mathrm{N}_{\mathrm{opt}}>\mathrm{SN}_{\mathrm{opt}}>\mathrm{SN}_{0}$.

The NGWP of the zero-N application treatments $\left(\mathrm{N}_{0}\right.$ and $\mathrm{SN}_{0}$ ) averaged $2702 \mathrm{~kg} \mathrm{CO}_{2}$-eq ha ${ }^{-1}$, with a positive GWP of $2748 \mathrm{~kg} \mathrm{CO}_{2}$-eq ha ${ }^{-1}$ (including a $9 \%$ contribution from $\mathrm{N}_{2} \mathrm{O}$ emissions, $12 \%$ from fertilizer production $(0 \%$ from $\mathrm{N}), 66 \%$ from power, $13 \%$ from fuel and pesticide) and a negative GWP of only $46 \mathrm{~kg} \mathrm{CO}_{2}$-eq ha ${ }^{-1}$ (including 72 and $28 \%$ from $\mathrm{CH}_{4}$ uptake and SOC sequestration, respectively). In contrast, the NGWP of optimum ( $\mathrm{N}_{\mathrm{opt}}$ and $\left.\mathrm{SN}_{\mathrm{opt}}\right)$ applications averaged $2853 \mathrm{~kg} \mathrm{CO}_{2}$-eq ha ${ }^{-1}$, with a positive GWP of $5525 \mathrm{~kg} \mathrm{CO}_{2}$-eq ha ${ }^{-1}$ (including an $18 \%$ contribution from $\mathrm{N}_{2} \mathrm{O}$ emissions, $43 \%$ from fertilizer production ( $37 \%$ from N), $33 \%$ from power, $6 \%$ from fuel and pesticide) and a negative GWP of $2672 \mathrm{~kg} \mathrm{CO}_{2}$-eq ha ${ }^{-1}$ (including $99 \%$ from SOC sequestration). The NGWP of the conventional $\mathrm{N}\left(\mathrm{N}_{\text {con }}\right.$ and $\left.\mathrm{SN}_{\text {con }}\right)$ applications averaged $4309 \mathrm{~kg}$ $\mathrm{CO}_{2}$-eq ha ${ }^{-1}$, with a positive GWP of $8986 \mathrm{~kg} \mathrm{CO}_{2}$-eq ha ${ }^{-1}$ (including a $20 \%$ contribution from $\mathrm{N}_{2} \mathrm{O}$ emissions, $54 \%$ from fertilizer production ( $51 \%$ from N), $20 \%$ from power and $6 \%$ from fuel and pesticide), and a negative GWP of $4677 \mathrm{~kg} \mathrm{CO}_{2}$-eq ha ${ }^{-1}$ (including $99 \%$ from SOC sequestration). The optimum $\mathrm{N}$ application reduced $\mathrm{CO}_{2}$-eq ha ${ }^{-1}$ by $3462 \mathrm{~kg}$ by reducing $\mathrm{N}_{2} \mathrm{O}$ emissions $(25 \%)$ and $\mathrm{N}$ fertilizer (75\%) compared to the conventional $\mathrm{N}$ application, but the latter fixed over $2006 \mathrm{~kg} \mathrm{CO}_{2}$-eq ha ${ }^{-1}$ more than the optimum $\mathrm{N}$ application through increasing SOC. Thus, the optimum $\mathrm{N}$ application led to a reduction of only $1456 \mathrm{~kg}$ $\mathrm{CO}_{2}$-eq ha ${ }^{-1}$ compared to the conventional $\mathrm{N}$ application, which accounted for $34 \%$ of NGWP in the latter.

Comparing the two straw management practices, the net GWP of the straw removal treatments $\left(\mathrm{N}_{0}, \mathrm{~N}_{\text {opt }}\right.$ and $\left.\mathrm{N}_{\text {con }}\right)$ averaged $3873 \mathrm{~kg} \mathrm{CO}_{2}$-eq ha ${ }^{-1}$, with a positive GWP of $5558 \mathrm{~kg} \mathrm{CO}_{2}$-eq ha ${ }^{-1}$ (including a $15 \%$ contribution from $\mathrm{N}_{2} \mathrm{O}$ emissions, $46 \%$ from chemical fertilizer production and transport ( $40 \%$ from N), $32 \%$ from power and $7 \%$ from fuel and pesticide) and a negative GWP of $1685 \mathrm{~kg} \mathrm{CO}_{2}$-eq ha ${ }^{-1}$ (including $98 \%$ from SOC sequestration). In comparison, the NGWP of the straw return treatments $\left(\mathrm{SN}_{0}, \mathrm{SN}_{\mathrm{opt}} \&\right.$ $\mathrm{SN}_{\text {con }}$ ) averaged $2703 \mathrm{~kg} \mathrm{CO}_{2}$-eq ha ${ }^{-1}$ with a positive GWP of $5948 \mathrm{~kg} \mathrm{CO}_{2}$-eq ha ${ }^{-1}$ (including a $20 \%$ contribution from 
Table 5. $\mathrm{N}_{2} \mathrm{O}$ emissions $\left(\mathrm{kg} \mathrm{N}_{2} \mathrm{O}-\mathrm{N} \mathrm{ha}^{-1}\right)$ in winter wheat-summer maize double-cropping system from June 2011 to June 2013.

\begin{tabular}{|c|c|c|c|c|c|c|c|c|}
\hline \multicolumn{2}{|c|}{ Treatments $^{\mathrm{a}}$} & \multirow{2}{*}{$\begin{array}{l}2011 \\
\mathrm{SM}^{\mathrm{b}}\end{array}$} & \multirow{2}{*}{$\begin{array}{l}\text { 2011-2012 } \\
\text { WW }\end{array}$} & \multirow{2}{*}{$\begin{array}{l}\text { 2011-2012 } \\
\text { Annual }\end{array}$} & \multirow{2}{*}{$\begin{array}{l}2012 \\
\text { SM }\end{array}$} & \multirow{2}{*}{$\begin{array}{l}\text { 2012-2013 } \\
\text { WW }\end{array}$} & \multirow{2}{*}{$\begin{array}{l}\text { 2012-2013 } \\
\text { Annual }\end{array}$} & \multirow{2}{*}{$\begin{array}{l}\text { 2011-2013 } \\
\text { Mean annual }\end{array}$} \\
\hline Nitrogen & Straw & & & & & & & \\
\hline \multicolumn{9}{|c|}{ Treatment effect $(n=3)$} \\
\hline $\mathrm{N}_{0}$ & & $0.09 \pm 0.02 c$ & $0.11 \pm 0.02 c$ & $0.20 \pm 0.04 c$ & $0.17 \pm 0.04 e$ & $0.30 \pm 0.05 c$ & $0.47 \pm 0.09 c$ & $0.34 \pm 0.03 d$ \\
\hline $\mathrm{N}_{0}$ & $S$ & $0.20 \pm 0.15 c$ & $0.34 \pm 0.11 b c$ & $0.54 \pm 0.16 c$ & $0.19 \pm 0.07 e$ & $0.64 \pm 0.17 b c$ & $0.83 \pm 0.21 b c$ & $0.69 \pm 0.17 d$ \\
\hline $\mathrm{N}_{\text {opt }}$ & & $1.09 \pm 0.33 b c$ & $0.89 \pm 0.29 a b c$ & $1.99 \pm 0.25 b c$ & $0.72 \pm 0.06 d$ & $0.75 \pm 0.46 b c$ & $1.48 \pm 0.45 b$ & $1.73 \pm 0.34 c$ \\
\hline $\mathrm{N}_{\mathrm{opt}}$ & $\mathrm{S}$ & $1.18 \pm 0.62 b c$ & $0.98 \pm 0.19 a b c$ & $2.16 \pm 0.49 b c$ & $1.21 \pm 0.04 c$ & $1.43 \pm 0.65 a b$ & $2.65 \pm 0.63 a$ & $2.40 \pm 0.26 b c$ \\
\hline $\mathrm{N}_{\text {con }}$ & & $1.80 \pm 0.65 a b$ & $1.47 \pm 0.85 a b$ & $3.27 \pm 0.83 a b$ & $1.97 \pm 0.20 b$ & $1.50 \pm 0.56 a b$ & $3.47 \pm 0.40 a$ & $3.37 \pm 0.32 a b$ \\
\hline $\mathrm{N}_{\text {con }}$ & $\mathrm{S}$ & $2.71 \pm 1.05 a$ & $1.83 \pm 1.00 a$ & $4.54 \pm 1.85 a$ & $2.39 \pm 0.41 a$ & $1.96 \pm 0.63 a$ & $4.35 \pm 0.64 a$ & $4.45 \pm 1.31 a$ \\
\hline \multicolumn{9}{|c|}{ Nitrogen effect $(n=6)$} \\
\hline & mean & $0.15 \pm 0.08 c$ & $0.23 \pm 0.05 b$ & $0.37 \pm 0.09 c$ & $0.18 \pm 0.05 c$ & $0.47 \pm 0.09 b$ & $0.65 \pm 0.12 c$ & $0.51 \pm 0.08 c$ \\
\hline $\mathrm{N}_{\mathrm{o}}$ & tmean & $1.14 \pm 0.47 b$ & $0.94 \pm 0.23 a b$ & $2.07 \pm 0.36 b$ & $0.97 \pm 0.05 b$ & $1.09 \pm 0.47 a b$ & $2.06 \pm 0.45 b$ & $2.07 \pm 0.29 b$ \\
\hline $\mathrm{N}_{\mathrm{c}}$ & nean & $2.26 \pm 0.81 a$ & $1.65 \pm 0.40 a$ & $3.90 \pm 1.20 a$ & $2.18 \pm 0.18 a$ & $1.73 \pm 0.68 a$ & $3.91 \pm 0.66 a$ & $3.90 \pm 0.69 a$ \\
\hline \multicolumn{9}{|c|}{ Straw effect $(n=9)$} \\
\hline With & ut straw & $1.00 \pm 0.28 a$ & $0.82 \pm 0.20 a$ & $1.82 \pm 0.34 a$ & $0.95 \pm 0.07 b$ & $0.85 \pm 0.34 a$ & $1.81 \pm 0.27 b$ & $1.81 \pm 0.19 b$ \\
\hline Wi & straw & $1.36 \pm 0.60 a$ & $1.05 \pm 0.40 a$ & $2.41 \pm 0.82 a$ & $1.27 \pm 0.16 a$ & $1.34 \pm 0.27 a$ & $2.61 \pm 0.46 a$ & $2.51 \pm 0.48 a$ \\
\hline
\end{tabular}

${ }^{a} \mathrm{~N}_{0}, \mathrm{~N}_{\mathrm{opt}}$ and $\mathrm{N}_{\text {con }}$ represent zero-N (control), optimum and conventional $\mathrm{N}$, respectively. $\mathrm{S}$ is straw return. ${ }^{\mathrm{b}} \mathrm{WW}$ and $\mathrm{SM}$ are winter wheat and summer maize; number represents mean \pm standard error $(n=3)$; different letters within same column indicate significant differences $(P<0.05)$

Table 6. Net global warming potential (NGWP) and greenhouse gas intensity (GHGI) in winter wheat-summer maize double-cropping system from June 2011 to June 2013.

\begin{tabular}{|c|c|c|c|c|c|c|c|c|c|c|c|c|c|}
\hline \multicolumn{2}{|c|}{ Treatments* } & \multirow[t]{3}{*}{$\mathrm{N}_{2} \mathrm{O}$} & \multirow[t]{3}{*}{$\mathrm{CH}_{4}$} & \multirow[t]{3}{*}{ SOC } & \multicolumn{3}{|c|}{ Fertilizer } & \multirow[t]{2}{*}{ Power } & \multirow[t]{3}{*}{ Fuel } & \multirow[t]{3}{*}{ Pesticide } & \multirow[t]{3}{*}{ Net GWP } & \multirow{3}{*}{$\begin{array}{c}\text { Grain yield } \\
\mathrm{Mg} \mathrm{ha}^{-1}\end{array}$} & \multirow{3}{*}{$\begin{array}{r}\text { GHGI } \\
\mathrm{q} \mathrm{Mg}^{-1}\end{array}$} \\
\hline & & & & & $\mathrm{N}$ & $\mathrm{P}_{2} \mathrm{O}_{5}$ & $\mathrm{~K}_{2} \mathrm{O}$ & & & & & & \\
\hline Nitrogen & Straw & & & & \multicolumn{4}{|c|}{$\mathrm{kg} \mathrm{CO}_{2}$-eq ha ${ }^{-1}$} & & & & & \\
\hline $\mathrm{N}_{0}$ & & 159 & -33 & -1437 & 0 & 242 & 88 & 1801 & 252 & 112 & 4058 & 7.2 & 562 \\
\hline $\mathrm{N}_{0}$ & $\mathrm{~S}$ & 323 & -33 & 1463 & 0 & 242 & 88 & 1801 & 276 & 112 & 1346 & 7.4 & 181 \\
\hline $\mathrm{N}_{\text {opt }}$ & & 810 & -33 & 2387 & 1992 & 242 & 88 & 1801 & 252 & 112 & 2877 & 11.1 & 258 \\
\hline$N_{\text {opt }}$ & $\mathrm{S}$ & 1124 & -33 & 2889 & 2108 & 242 & 88 & 1801 & 276 & 112 & 2829 & 11.2 & 252 \\
\hline $\mathrm{N}_{\text {con }}$ & & 1578 & -33 & 4004 & 4648 & 242 & 88 & 1801 & 252 & 112 & 4684 & 11.9 & 393 \\
\hline $\mathrm{N}_{\text {con }}$ & $\mathrm{S}$ & 2084 & -33 & 5284 & 4648 & 242 & 88 & 1801 & 276 & 112 & 3934 & 12.7 & 310 \\
\hline \multicolumn{14}{|c|}{ Nitrogen management } \\
\hline & $\mathrm{J}_{0}$ & 241 & -33 & 13 & 0 & 242 & 88 & 1801 & 264 & 112 & 2702 & 7.3 & 369 \\
\hline & opt & 967 & -33 & 2638 & 2050 & 242 & 88 & 1801 & 264 & 112 & 2853 & 11.2 & 255 \\
\hline & con & 1831 & -33 & 4644 & 4648 & 242 & 88 & 1801 & 264 & 112 & 4309 & 12.3 & 350 \\
\hline \multicolumn{14}{|c|}{ Straw management } \\
\hline \multirow{2}{*}{\multicolumn{2}{|c|}{ Without straw }} & 849 & -33 & 1651 & 2213 & 242 & 88 & 1801 & 252 & 112 & 3873 & 10.1 & 384 \\
\hline & & 1177 & -33 & 3212 & 2252 & 242 & 88 & 1801 & 276 & 112 & 2703 & 10.4 & 259 \\
\hline
\end{tabular}

$\mathrm{N}_{2} \mathrm{O}$ emissions, $43 \%$ from chemical fertilizer production and transport ( $38 \%$ from N), $30 \%$ from power and $7 \%$ from fuel and pesticide) and a negative GWP of $3245 \mathrm{~kg} \mathrm{CO}_{2}$-eq ha ${ }^{-1}$ (including $99 \%$ from SOC sequestration). Compared to the straw removal treatments, the positive GWP in the straw return treatments increased by $391 \mathrm{~kg} \mathrm{CO}_{2}$-eq ha ${ }^{-1}, 84 \%$ of which is from the increment of $\mathrm{N}_{2} \mathrm{O}$ emissions, $10 \%$ from higher $\mathrm{N}$ input and $7 \%$ from straw return, but the negative GWP also increased by $1561 \mathrm{~kg} \mathrm{CO}_{2}$-eq ha ${ }^{-1}$ because of more SOC sequestration after straw return, so the NGWP in the straw return treatments decreased by $1170 \mathrm{~kg} \mathrm{CO}_{2}$-eq $\mathrm{ha}^{-1}$ compared to straw removal, accounting for $30 \%$ of NGWP in the latter.

The GHGI across all treatments ranged from 181 to $562 \mathrm{~kg} \mathrm{CO}_{2}$-eq $\mathrm{Mg}^{-1}$ grain and followed the order
$\mathrm{N}_{0}>\mathrm{N}_{\text {con }}>\mathrm{SN}_{\text {con }}>\mathrm{N}_{\text {opt }}>\mathrm{SN}_{\text {opt }}>\mathrm{SN}_{0}$ (Table 6). Comparing the three $\mathrm{N}$ levels, the GHGI of zero- $\mathrm{N}$ applications $\left(\mathrm{N}_{0}\right.$ and $\left.\mathrm{SN}_{0}\right)$ averaged $369 \mathrm{~kg} \mathrm{CO}$-eq $\mathrm{Mg}^{-1}$ grain, including contributions of $34,45,246,51,-5$ and $-2 \mathrm{CO}_{2}$ eq $\mathrm{Mg}^{-1}$ from $\mathrm{N}_{2} \mathrm{O}$ emissions, fertilizer production and transport, power, other sources, $\mathrm{CH}_{4}$ uptake and SOC sequestration, respectively. In contrast, the GHGI of the optimum $\left(\mathrm{N}_{\mathrm{opt}}\right.$ and $\left.\mathrm{SN}_{\mathrm{opt}}\right) \mathrm{N}$ applications averaged $255 \mathrm{~kg}$ $\mathrm{CO}_{2}$-eq $\mathrm{Mg}^{-1}$ grain, including contributions of $86,183,161$, 64 and $-236 \mathrm{~kg} \mathrm{CO}_{2}$-eq $\mathrm{Mg}^{-1}$ grain from $\mathrm{N}_{2} \mathrm{O}$ emissions, $\mathrm{N}$ fertilizer production, power, other sources and SOC sequestration, respectively. The GHGI of conventional $\left(\mathrm{N}_{\text {con }}\right.$ and $\left.\mathrm{SN}_{\text {con }}\right) \mathrm{N}$ application averaged $350 \mathrm{~kg} \mathrm{CO}_{2}$-eq $\mathrm{Mg}^{-1}$ grain, including contributions of $149,378,146,58$ and $-378 \mathrm{~kg} \mathrm{CO}_{2}$-eq $\mathrm{Mg}^{-1}$ grain from $\mathrm{N}_{2} \mathrm{O}$ emissions, $\mathrm{N}$ fer- 


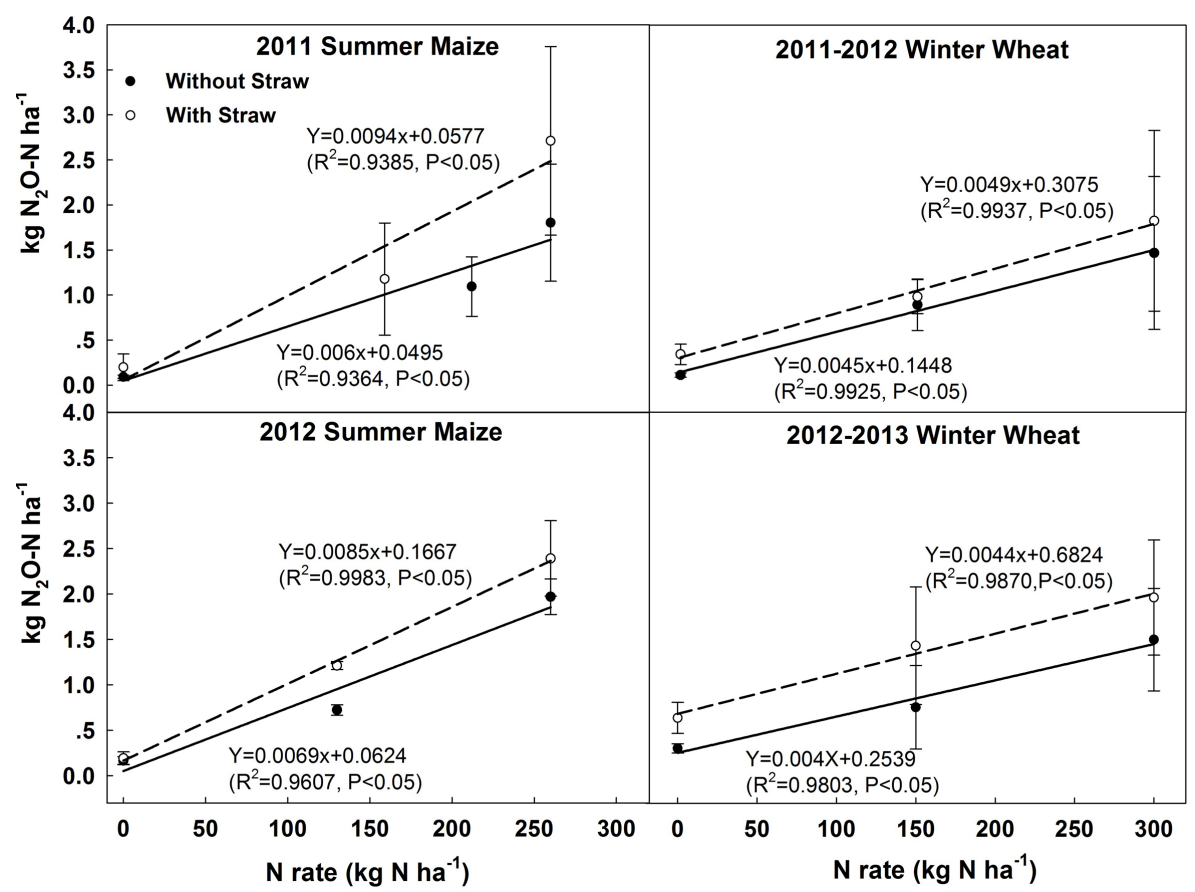

Fig. 4. Correlations between seasonal cumulative $\mathrm{N}_{2} \mathrm{O}$ emissions and fertilizer $\mathrm{N}$ application rates from 2011 to 2013 . The dashed line and solid line were fitted by linear regression from the straw and without straw treatments, respectively.

tilizer production, power, other sources and SOC sequestration, respectively. Compared to conventional $\mathrm{N}$ application, the GHGI at the optimum $\mathrm{N}$ treatment decreased by $95 \mathrm{~kg} \mathrm{CO}_{2}$-eq $\mathrm{Mg}^{-1}$ grain, with 62,193 and $-142 \mathrm{~kg}$ $\mathrm{CO}_{2}$-eq $\mathrm{Mg}^{-1}$ grain of this due to a decrease in $\mathrm{N}_{2} \mathrm{O}$ emissions, $\mathrm{N}$ fertilizer production and transport, and SOC sequestration, and $18 \mathrm{~kg} \mathrm{CO}_{2}$-eq $\mathrm{Mg}^{-1}$ grain due to an increase from other sources. Compared to straw removal, although the GHGI with straw return was $28 \mathrm{~kg} \mathrm{CO}_{2}$-eq $\mathrm{Mg}^{-1}$ grain due to a increase in $\mathrm{N}_{2} \mathrm{O}$ emissions, this was offset by 144 and $9 \mathrm{~kg} \mathrm{CO}_{2}$-eq $\mathrm{Mg}^{-1}$ grain due to $\mathrm{SOC}$ sequestration and other sources, and finally decreased by $125 \mathrm{~kg} \mathrm{CO}_{2}$-eq $\mathrm{Mg}^{-1}$ grain.

\section{Discussion}

\subsection{Effects of $\mathrm{N}$ application and straw return on grain yields}

The mean grain yields (dry matter) of winter wheat $\left(5.0 \mathrm{Mg} \mathrm{ha}^{-1}\right)$ and summer maize $\left(6.8 \mathrm{Mg} \mathrm{ha}^{-1}\right)$ from the $\mathrm{N}$ application treatments $\left(\mathrm{N}_{\mathrm{opt}}\right.$ and $\left.\mathrm{N}_{\text {con }}\right)$ in this study (Table 3) were comparable to the normal average yield in conventional farming practice on the $\mathrm{NCP}$ (wheat $5.5 \mathrm{Mg} \mathrm{ha}^{-1}$, maize 5.5$6.0 \mathrm{Mg} \mathrm{ha}^{-1}$ ) as reported by Zhao et al. (2006), and lower than the potential productivity (wheat $6.9 \mathrm{Mg} \mathrm{ha}^{-1}$, maize $8.3 \mathrm{Mg} \mathrm{ha}^{-1}$ ) based on the results of experiments conducted in the region (Wang et al., 2010). This further supports the argument that about half of the conventional $\mathrm{N}$ application rate could be used to achieve comparable crop yields because the conventional practice has involved substantial over-use of chemical $\mathrm{N}$ fertilizers over the last decade, leading to pollution of surface waters and groundwater and high emissions of reactive $\mathrm{N}$ to the atmosphere (Ju et al., 2009; Guo et al., 2010; Liu et al., 2013). There is considerable scope for saving $\mathrm{N}$ fertilizer to restore the environment and maintain relatively high crop productivity.

It was locally common practice to remove straw and burn it as a household fuel about 20 years ago, but nowadays most straw is returned to the field because of a switch of household fuel to coal or natural gas (Edwards et al., 2004). These changes provide good opportunities to enhance soil fertility, store more carbon in the soil and boost crop yields (Huang and Sun, 2006). As shown in our study, straw return slightly increased winter wheat and summer maize yields (Table 3) and might increase the yields significantly as the experiment continues over the longer term (Malhi et al., 2011).

\subsection{Impacts of $\mathrm{N}$ application and straw return on SOC sequestration and $\mathrm{N}_{2} \mathrm{O}$ emissions}

SOC density change represents the net $\mathrm{CO}_{2}$ exchange between the atmosphere and soil (Mosier et al., 2006; Shang et al., 2011). It has been reported that chemical $\mathrm{N}$ fertilizer can increase the SOC content, especially with incorporation of straw (Huang and Sun, 2006), but the magnitude of the increase is subject to considerable temporal and spatial variation depending on initial SOC content, soil-climatic 
conditions, management practices such as tillage, and cropping systems (Zhang et al., 2010). A local $25 \mathrm{yr}$ old field experiment showed that the SOC content in the top $20 \mathrm{~cm}$ increased by $10-53 \%$ compared with the control with $\mathrm{N}$ fertilizer application and maize straw return (Du et al., 2009). In our study the rate of increase of SOC density ranged from 0.04 to $1.44 \mathrm{Mg} \mathrm{Cha}^{-1} \mathrm{yr}^{-1}$, similar to previous reports from work in the uplands of northern China $(0.07-1.461 \mathrm{Mg}$ $\mathrm{Cha}^{-1} \mathrm{yr}^{-1}$ ) (Zhang et al., 2010). However, the change was very slow due to the decomposition of the straw coupled with high soil temperatures and moisture in summer on the NCP (Huang et al., 2013).

The processes, patterns and factors controlling $\mathrm{N}_{2} \mathrm{O}$ emissions have been reported by several studies recently (Ju et al., 2011; Cui et al., 2012; Hu et al., 2013), i.e. $\mathrm{N}_{2} \mathrm{O}$ emission peaks occurring mainly within one or two weeks of $\mathrm{NH}_{4}^{+}$based fertilizer application and irrigation, and the occurrence of emissions mainly during the summer maize season with combined high soil temperatures and moisture. Our results are in line with these earlier studies. $\mathrm{N}_{2} \mathrm{O}$ emissions usually increase linearly or exponentially with increasing $\mathrm{N}$ application rate, and thus reduction of the $\mathrm{N}$ rate to an optimum level could substantially reduce $\mathrm{N}_{2} \mathrm{O}$ emissions in cropping systems (Van Groenigen et al., 2010; Liu et al., 2012). Our former results using an automated system showed that total $\mathrm{N}_{2} \mathrm{O}$ emissions decreased by 40 and $67 \%$ in the winter wheat and summer maize seasons, respectively, when the conventional $\mathrm{N}$ management ( $300 \mathrm{~kg} \mathrm{Nha}^{-1}$ per crop) changed to optimum $\mathrm{N}$ management (50-122 $\mathrm{kg} \mathrm{Nha}^{-1}$ per crop) (Ju et al., 2011), which is similar to the $37-56 \%$ reduction in the present study.

Straw return consistently increased $\mathrm{N}_{2} \mathrm{O}$ emissions and showed positive interactions between $\mathrm{N}$ and straw, especially in the summer maize season (Fig. 4). This indicates that the $\mathrm{N}_{2} \mathrm{O}$ emissions from the straw incorporation treatments were 4 times higher than the straw removal treatments (Hao et al., 2001). In addition, $\mathrm{N}_{2} \mathrm{O}$ emissions increased by $58 \%$ in the following summer maize after wheat straw return (Liu et al., 2011). This increase may have been due to accelerating microbial nitrification and denitrification processes with the coupling of mineral $\mathrm{N}$, available carbon, and favourable temperatures and soil moisture (Huang et al., 2004).

\subsection{Impacts of $\mathrm{N}$ application and straw return on NGWP and GHGI}

Agricultural management practices that change one type of GWP source/sink may also impact other sources/sinks and therefore change the NGWP and GHGI (Mosier et al., 2006; Shang et al., 2011). In the present study a $56 \%$ decrease in $\mathrm{N}$ fertilizer to the $\mathrm{N}_{\mathrm{opt}}$ treatment brought about a $47 \%$ decrease in $\mathrm{N}_{2} \mathrm{O}$ emissions, a $56 \%$ decrease in $\mathrm{N}$ fertilizer manufacture and transport, a $43 \%$ decrease in SOC sequestration, and finally a $34 \%$ decrease in the net GWP relative to the $\mathrm{N}_{\text {con }}$ treatment. However, despite the lower $\mathrm{N}$ fertilizer input, the grain yield declined by only $9 \%$ (and not significantly) and the GHGI of the $\mathrm{N}_{\mathrm{opt}}$ treatment was $27 \%$ lower than the $\mathrm{N}_{\text {con }}$ treatment, indicating less $\mathrm{CO}_{2}$-eq consumption per unit grain produced. Similarly, compared to the straw removal treatments, straw return generated a $28 \%$ increase in $\mathrm{N}_{2} \mathrm{O}$ emissions, $9 \%$ increase in fuel consumption for straw returning, a $49 \%$ increase in SOC sequestration, and finally 30 and $33 \%$ decreases in NGWP and GHGI, respectively. Thus, this indicates that relatively high yields and lower carbon costs can be achieved simultaneously by optimizing Nand straw management.

The NGWP in our study (1346-4684 $\mathrm{kg} \mathrm{CO}_{2}$-eq ha ${ }^{-1}$ ) was much lower than in rice-wheat rotations $(6660-9710 \mathrm{~kg}$ $\mathrm{CO}_{2}$-eq ha ${ }^{-1}$ ) (Ma et al., 2013) and double-rice-cropping systems (13 407-26066 $\mathrm{kg} \mathrm{CO}_{2}$-eq ha ${ }^{-1}$ ) (Shang et al., 2011), in both of which $\mathrm{CH}_{4}$ emission was the main contributor to the high GWP. However, $\mathrm{CH}_{4}$ is a very small sink in our upland cropping system and $\mathrm{CH}_{4}$ uptake makes little contribution when calculating the NGWP from all emissions and sinks. We therefore adopted the $\mathrm{CH}_{4}$ uptake data from previous field experiments carried out on the same soil type, climatic zone and cropping system, and the annual and treatment variation in $\mathrm{CH}_{4}$ uptake was very small (e.g. 0.74$1.16 \mathrm{~kg} \mathrm{CH}_{4}-\mathrm{Cha}^{-1}$ in $2009-2010$ and $0.69-0.93 \mathrm{~kg} \mathrm{CH}_{4}-$ $\mathrm{C} \mathrm{ha}^{-1}$ in 2010-2011 across all treatments) (Gao, 2012; Hu et al., 2013). The effect of nitrogen and straw on cumulative $\mathrm{CH}_{4}$ uptake in this region is very small (Liu et al., 2012) and the negative GWP from $\mathrm{CH}_{4}$ uptake represented less than $1 \%$ in all GWP calculations.

The GHGI values of the $\mathrm{N}$ application treatments were 252-393 $\mathrm{kg} \mathrm{CO}_{2}$-eq $\mathrm{Mg}^{-1}$ grain in this study, higher than the values from irrigated maize in central Nebraska, where the GHGI was $230 \mathrm{~kg} \mathrm{CO}_{2}$-eq $\mathrm{Mg}^{-1}$ grain (Grassini and Cassman, 2012) because of low emission factors for $\mathrm{N}$ fertilizer production $\left(2.6 \mathrm{~kg} \mathrm{CO}_{2}\right.$-eq kg ${ }^{-1}$ in the US vs. $8.3 \mathrm{~kg}$ $\mathrm{CO}_{2}$-eq kg ${ }^{-1}$ in China) and electricity generation $(0.6 \mathrm{~kg}$

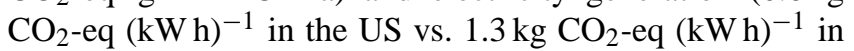
China) (Grassini and Cassman, 2012; Zhang et al., 2013). The higher emission factor was due 70 and $86 \%$ to Chinese primary energy consumption and the energy consumed in $\mathrm{N}$ fertilizer production being dependent on coal (Crompton and $\mathrm{Wu}, 2005$; Zhang et al., 2013), which has a greater GWP (methane and carbon dioxide emission from mining and combustion of coal) and lower energy efficiency than other sources of energy such as natural gas and nuclear power (Zhang et al., 2013). In the present study the GHGI from the $\mathrm{N}$ fertilizer and electricity production accounted for 37-50 and 19-34\% of the total positive GHGI, respectively. However, if we adopt the lower emission factor (4.7 $\mathrm{kg} \mathrm{CO}_{2}$-eq kg ${ }^{-1}$ ) for the $\mathrm{N}$ fertilizer industry in China by the best available technologies and a lower emission factor

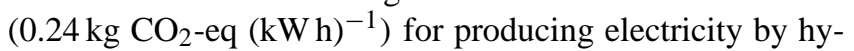
dro power (Zhang et al., 2013), the GHGI for the $\mathrm{N}$ application treatments will be reduced to $35-101 \mathrm{~kg} \mathrm{CO}_{2}$-eq $\mathrm{Mg}^{-1}$ grain. 
Our results show that $48-52 \%$ of positive GWP from the agricultural inputs has been offset by SOC sequestration with a low initial SOC content $\left(7.7 \mathrm{~g} \mathrm{~kg}^{-1}\right)$. However, this trend of increasing SOC content might slow down when it reaches a maximum soil $\mathrm{C}$ capacity, i.e. soil $\mathrm{C}$ saturation (West and Six, 2007). Moreover, different agricultural management practices that increase SOC will simultaneously change other types of greenhouse gas emissions (Robertson et al., 2000). Robertson et al. (2000) revealed that notill management enhanced SOC accumulation but concomitantly stimulated $\mathrm{N}_{2} \mathrm{O}$ emissions, which almost offset the negative GWP from SOC sequestration. Fertilizers and wheat residues applied to the soil will provide additional SOC in Ohio Crosby soil, but its greenhouse mitigating effect would be offset not only by increasing $\mathrm{N}_{2} \mathrm{O}$ emissions but also by SOC sequestration rates decreasing with time, and as a result the GWP-lowering effect of the fertilized and unfertilized treatments will vanish after 7 and 12 years, respectively (Jacinthe and Lal, 2003). Nevertheless, this overestimation of SOC sequestration is unlikely to change our conclusion that optimum $\mathrm{N}$ fertilization and straw return can both maintain relatively high target yields and also reduce environmental costs in our cropping system.

In our study the main emission sources are power consumption for irrigation, $\mathrm{N}$ production and $\mathrm{N}_{2} \mathrm{O}$ emissions, with the main emission sink being SOC sequestration. To further reduce the GWP of the winter wheat-summer maize cropping system in future, we firstly can change the current conventional cropping system (winter wheat-summer maize with two harvests in one year) to an alternative system (winter wheat/summer maize-spring maize with three harvests in two years or monoculture spring maize with one harvest each year) and reduce the power consumption for irrigating winter wheat as described by Meng et al. (2012). Secondly, we can reduce the GHG emissions generated from $\mathrm{N}$ fertilizer production by optimizing the $\mathrm{N}$ application rate ( $\mathrm{Ju}$ et al., 2011; Liu et al., 2012) and improving the technologies of fertilizer N manufacturing technologies (Zhang et al., 2013). Thirdly, $\mathrm{N}_{2} \mathrm{O}$ emissions can be reduced by using nitrification inhibitors (Ding et al., 2011) or polymer-coated controlledrelease fertilizers (Hu et al., 2013). Finally, although in this study the highest SOC had increased to $10.8 \mathrm{~g} \mathrm{~kg}^{-1}$ after 6 years, there was still potential to increase SOC further by manure application and reduced tillage (Smith et al., 2007; Snyder et al., 2009).

\section{Conclusions}

The conventional $\mathrm{N}$ application rate could be reduced by roughly half to the optimum level using the improved Nmin method and still maintain relatively high target yields and consequently significantly reduce $\mathrm{N}_{2} \mathrm{O}$ emissions. Straw return had a slight yield benefit and could increase annual $\mathrm{N}_{2} \mathrm{O}$ emissions but led to a significant increase in SOC. Ra- tional long-term $\mathrm{N}$ and straw return management can increase SOC sequestration, which can offset the $\mathrm{CO}_{2}$-eq from GHG emissions and agricultural inputs and consequently reduce NGWP and GHGI compared with conventional farming practices in this double-cropping system. The main emission sources are the power consumption for irrigation, fertilizer $\mathrm{N}$ production and $\mathrm{N}_{2} \mathrm{O}$ emissions, with $\mathrm{SOC}$ sequestration providing the main emission sink. Therefore, the NGWP and GHGI of this cropping system can be further decreased by water saving in the winter wheat season, improving the technologies of fertilizer $\mathrm{N}$ manufacture and reducing $\mathrm{N}_{2} \mathrm{O}$ emissions by using slow-release or controlled-release fertilizers.

Acknowledgements. This work was funded by the National Natural Science Foundation of China (31172033, 41230856), the Special Fund for the Agricultural Profession (201103039), and the Innovation Group Grant of the National Natural Science Foundation of China (31121062).

Edited by: A. Neftel

\section{References}

Chen, X. P., Cui, Z. L., Vitousek, P. M., Cassman, K. G., Matson, P. A., Bai, J. S., Meng, Q. F., Hou, P., Yue, S. C., Roemheld, V., and Zhang, F. S.: Integrated soil-crop system management for food security, P. Natl. Acad. Sci., 108, 6399-6404, 2011.

Cole, C. V., Duxbury, J., Freney, J., Heinemeyer, O., Minami, K., Mosier, A., Paustian, K., Rosenberg, N., Sampson, N., Sauerbeck, D., and Zhao, Q.: Global estimates of potential mitigation of greenhouse gas emissions by agriculture, Nutr. Cycl. Agroecosys., 49, 221-228, 1997.

Crompton, P. and Wu, Y. R.: Energy consumption in China: past trends and future directions, Energy Economics, 27, 195-208, 2005.

Cui, F., Yan, G. X., Zhou, Z. X., Zheng, X. H., and Deng, J.: Annual emissions of nitrous oxide and nitric oxide from a wheat-maize cropping system on a silt loam calcareous soil in the North China Plain, Soil Biol. Biochem., 48, 10-19, 2012.

Ding, W. X., Yu, H. Y., and Cai, Z. C.: Impact of urease and nitrification inhibitors on nitrous oxide emissions from fluvo-aquic soil in the North China Plain, Biol. Fert. Soils, 47, 91-99, 2011.

Du, Z. L., Liu, S., F., Li, K. J., and Ren, T. S.: Soil organic carbon and physical quality as influenced by long-term application of residue and mineral fertiliser in the North China Plain, Aust. J. Soil Res., 47, 585-591, 2009.

Edwards, R. D., Smith, K. R., Zhang, J. F., and Ma, Y. Q.: Implications of changes in household stoves and fuel use in China, Energ Policy, 32, 395-411, 2004.

Foley, J. A., Ramankutty, N., Brauman, K. A., Cassidy, E. S., Gerber, J. S., Johnston, M., Mueller, N. D., O'Connell, C., Ray, D. K., West, P. C., Balzer, C., Bennett, E. M., Carpenter, S. R., Hill, J., Monfreda, C., Polasky, S., Rockstrom, J., Sheehan, J., Siebert, S., Tilman, D., and Zaks, D. P. M.: Solutions for a cultivated planet, Nature, 478, 337-342, 2011.

Gao, B.: Greenhouse gases emissions and net global warming potential of difference cropping systems and management practices 
on the North China Plain. China Agricultural University PhD Thesis, Beijing, 79-80, 2012.

Gao, B., Ju, X. T., Zhang, Q., Christie, P., and Zhang, F. S.: New estimates of direct $\mathrm{N} 2 \mathrm{O}$ emissions from Chinese croplands from 1980 to 2007 using localized emission factors, Biogeosciences Discuss., 8, 6971-7006, doi:10.5194/bgd-8-6971-2011, 2011

Grassini, P. and Cassman, K. G.: High-yield maize with large net energy yield and small global warming intensity, P. Natl. Acad. Sci., 109, 1074-1079, 2012.

Guo, J. H., Liu, X. J., Zhang, Y., Shen, J. L., Han, W. X., Zhang, W. F., Christie, P., Goulding, K. W. T., Vitousek, P. M., and Zhang, F. S.: Significant Acidification in Major Chinese Croplands, Science, 327, 1008-1010, 2010.

Hao, X., Chang, C., Carefoot, J. M., Janzen, H. H., and Ellert, B. H.: Nitrous oxide emissions from an irrigated soil as affected by fertilizer and straw management, Nutr. Cycl. Agroecosys. 60, 18, 2001.

Hu, X. K., Su, F., Ju, X. T., Gao, B., Oenema, O., Christie, P., Huang, B. X., Jiang, R. F., and Zhang, F. S.: Greenhouse gas emissions from a wheat-maize double cropping system with different nitrogen fertilization regimes, Environ. Pollut., 176, 198207, 2013.

Huang, J. X., Chen, Y. Q., Liu, W. R., Zheng, H. B., Sui, P., Li, Y. Y., Shi, X. P., Nie, S. W., and Gao, W. S.: Effect on net greenhouse gases emission under different conservation tillages in Jilin Province, Scientia agricultura, Sinica, 44, 2935-2942, 2011.

Huang, T., Qiu, S. J., Du, J., Shi, Z. X., and Ju, X. T.: Effect of different carbon and nitrogen managements on yield, straw decomposition, soil $\mathrm{CO}_{2}$ flux of the winter wheat/summer maize, Scientia agricultura. Sinica, 46, 756-768, 2013.

Huang, Y. and Sun, W. J.: Changes in topsoil organic carbon of croplands in mainland China over the last two decades, Chinese Sci. Bull., 51, 1785-1803, 2006.

Huang, Y., Zou, J. W., Zheng, X. H., Wang, Y. S., and Xu, X. K.: Nitrous oxide emissions as influenced by amendment of plant residues with different $\mathrm{C}: \mathrm{N}$ ratios, Soil Biol. Biochem., 36, 973981, 2004.

IPCC: Changes in atmospheric constituents and in radiative forcing. Climate Change 2007: The Physical Science Basis, Contribution of Working Group I to the Fourth Assessment Report of the Intergovernmental Panel on Climate Change, edited by: Solomon, S., Qin, D., Manning, M., Chen, Z., Marquis, M., Averyt, K. B., Tignor, M., and Miller, H. L., Cambridge University Press, Cambridge, UK and New York, NY, USA, 130-234, 2007.

Jacinthe, P. A. and Lal, R.: Nitrogen fertilization of wheat residue affecting nitrous oxide and methane emission from a central Ohio Luvisol, Biol. Fert. Soils, 37, 338-347, 2003.

Ju, X. T., Lu, X., Gao, Z. L., Chen, X. P., Su, F., Kogge, M., Roemheld, V., Christie, P., and Zhang, F. S.: Processes and factors controlling $\mathrm{N}_{2} \mathrm{O}$ production in an intensively managed low carbon calcareous soil under sub-humid monsoon conditions, Environ. Pollut., 159, 1007-1016, 2011.

Ju, X. T., Xing, G. X., Chen, X. P., Zhang, S. L., Zhang, L. J., Liu, X. J., Cui, Z. L., Yin, B., Christie, P., Zhu, Z. L., and Zhang, F. $S .:$ Reducing environmental risk by improving $N$ management in intensive Chinese agricultural systems, P. Natl. Acad. Sci., 106, 3041-3046, 2009.

Kroon, P. S., Hensen, A., van den Bulk, W. C. M., Jongejan, P. A. C., and Vermeulen, A. T.: The importance of reducing the systematic error due to non-linearity in $\mathrm{N}_{2} \mathrm{O}$ flux measurements by static chambers, Nutr. Cycl. Agroecosys., 82, 175-186, 2008.

Liu, C. Y., Wang, K., Meng, S. X., Zheng, X. H., Zhou, Z. X., Han, S. H., Chen, D. L., and Yang, Z. P.: Effects of irrigation, fertilization and crop straw management on nitrous oxide and nitric oxide emissions from a wheat-maize rotation field in northern China, Agr. Ecosyst. Environ., 140, 226-233, 2011.

Liu, C., Wang, K., and Zheng, X.: Responses of $\mathrm{N}_{2} \mathrm{O}$ and $\mathrm{CH} 4$ fluxes to fertilizer nitrogen addition rates in an irrigated wheatmaize cropping system in northern China, Biogeosciences, 9, 839-850, doi:10.5194/bg-9-839-2012, 2012.

Liu, X. J., Zhang, Y., Han, W. X., Tang, A. H., Shen, J. L., Cui, Z. L., Vitousek, P., Erisman, J. W., Goulding, K., Christie, P., Fangmeier, A., and Zhang, F. S.: Enhanced nitrogen deposition over China, Nature, 494, 459-462, 2013.

Livingston, G. P., Hutchinson, G. L., and Spartalian, K.: Diffusion theory improves chamber-based measurements of trace gas emissions, Geophys. Res. Lett., 32, L24817, doi:10.1029/2005GL024744, 2005.

Ma, Y. C., Kong, X. W., Yang, B., Zhang, X. L., Yan, X. Y., Yang, J. C., and Xiong, Z. Q.: Net global warming potential and greenhouse gas intensity of annual rice-wheat rotations with integrated soil-crop system management, Agr. Ecosyst. Environ., 164, 209219, 2013.

Malhi, S. S., Nyborg, M., Solberg, E. D., Dyck, M. F., and Puurveen, D.: Improving crop yield and $\mathrm{N}$ uptake with long-term straw retention in two contrasting soil types, Field Crop Res., 124, 378391, 2011.

Meng, Q. F., Sun, Q. P., Chen, X. P., Cui, Z. L., Yue, S. C., Zhang, F. S., and Roemheld, V.: Alternative cropping systems for sustainable water and nitrogen use in the North China Plain, Agr. Ecosyst. Environ., 146, 93-102, 2012.

Mosier, A. R., Halvorson, A. D., Reule, C. A., and Liu, X. J.: Net global warming potential and greenhouse gas intensity in irrigated cropping systems in northeastern Colorado, J. Environ. Qual., 35, 1584-1598, 2006.

Pathak, H., Li, C., and Wassmann, R.: Greenhouse gas emissions from Indian rice fields: calibration and upscaling using the DNDC model, Biogeosciences, 2, 113-123, doi:10.5194/bg-2113-2005, 2005.

Qiu, S. J., Ju, X. T., Lu, X., Li, L., Ingwersen, J., Streck, T., Christie, P., and Zhang, F. S.: Improved nitrogen management for an intensive winter wheat/summer maize double-cropping system, Soil Sci. Soc. Am. J., 76, 286-297, 2012.

Robertson, G. P. and Grace, P. R.: Greenhouse gas fluxes in tropical and temperate agriculture: The need for a full-cost accounting of global warming potentials, Environment Development and Sustainability, 6, 51-63, 2004.

Robertson, G. P., Paul, E. A., and Harwood, R. R.: Greenhouse gases in intensive agriculture: Contributions of individual gases to the radiative forcing of the atmosphere, Science, 289, 19221925, 2000.

Shang, Q. Y., Yang, X. X., Gao, C. M., Wu, P. P., Liu, J. J., Xu, Y. C., Shen, Q. R., Zou, J. W., and Guo, S. W.: Net annual global warming potential and greenhouse gas intensity in Chinese double rice-cropping systems: a 3-year field measurement in longterm fertilizer experiments, Global Change Biol., 17, 2196-2210, 2011. 
Smith, P., Martino, D., Cai, Z. C., Gwary, D., Janzen, H., Kumar, P., McCarl, B., Ogle, S., O’Mara, F., Rice, C., Scholes, B., Sirotenko, O., Howden, M., McAllister, T., Pan, G. X., Romanenkov, V., Schneider, U., and Towprayoon, S.: Policy and technological constraints to implementation of greenhouse gas mitigation options in agriculture, Agr. Ecosyst. Environ., 118, 6-28, 2007.

Smith, P., Fang, C. M., Dawson, J. J. C., and Moncrieff, J. B.: Impact of global warming on soil organic carbon, Advances in Agronomy, 97, 1-43, 2008.

Snyder, C. S., Bruulsema, T. W., Jensen, T. L., and Fixen, P. E.: Review of greenhouse gas emissions from crop production systems and fertilizer management effects, Agr. Ecosyst. Environ., 133, 247-266, 2009.

Song, L. N., Zhang, Y. M., Hu, C. S., Zhang, X. Y., Dong, W. X., Wang, Y. Y., and Qin, S. P.: Comprehensive analysis of emissions and global warming effects of greenhouse gases in winter-wheat fields in the high-yield agro-region of North China Plain, Chinese Journal of Eco-Agriculture, 21, 297-307, 2013.

Tilman, D., Cassman, K. G., Matson, P. A., Naylor, R., and Polasky, S.: Agricultural sustainability and intensive production practices, Nature, 418, 671-677, 2002.

Van Groenigen, J. W., Velthof, G. L., Oenema, O., Van Groenigen, K. J., and Van Kessel, C.: Towards an agronomic assessment of $\mathrm{N}_{2} \mathrm{O}$ emissions: a case study for arable crops, Eur. J. Soil Sci., 61, 903-913, 2010.
Wang, H. X., Liu, C. M., and Zhang, L.: Water-saving agriculture in China: An overview, Advances in Agronomy, 75, 135-171, 2002.

Wang, Y. C., Wang, E. L., Wang, D. L., Huang, S. M., Ma, Y. B., Smith, C. J., and Wang, L. G.: Crop productivity and nutrient use efficiency as affected by long-term fertilisation in North China Plain, Nutr. Cycl. Agroecosys., 86, 105-119, 2010.

West, T. O. and Six, J.: Considering the influence of sequestration duration and carbon saturation on estimates of soil carbon capacity, Climatic Change, 80, 25-41, 2007.

Zhang, W. F., Dou, Z. X., He, P., Ju, X. T., Powlson, D., Chadwick, D., Norse, D., Lu, Y. L., Zhang, Y., Wu, L., Chen, X. P., Cassman, K. G., and Zhang, F. S.: New technologies reduce greenhouse gas emissions from nitrogenous fertilizer in China, P. Natl. Acad. Sci., 110, 8375-8380, 2013.

Zhang, W. J., Wang, X. J., Xu, M. G., Huang, S. M., Liu, H., and Peng, C.: Soil organic carbon dynamics under long-term fertilizations in arable land of northern China, Biogeosciences, 7, 409-425, 2010, http://www.biogeosciences.net/7/409/2010/.

Zhao, R. F., Chen, X. P., Zhang, F. S., Zhang, H. L., Schroder, J., and Roemheld, V.: Fertilization and nitrogen balance in a wheatmaize rotation system in North China, Agron. J., 98, 938-945, 2006.

Zheng, X. H., Mei, B. L., Wang, Y. H., Xie, B. H., Wang, Y. S., Dong, H. B., Xu, H., Chen, G. X., Cai, Z. C., Yue, J., Gu, J. X., $\mathrm{Su}$, F., Zou, J. W., and Zhu, J. G. Quantification of $\mathrm{N}_{2} \mathrm{O}$ fluxes from soil-plant systems may be biased by the applied gas chromatograph methodology, Plant Soil, 311, 211-234, 2008. 